\title{
SAHARAN DUST INPUTS TO THE W. MEDITERRANEAN SEA: DEPOSITIONAL PATTERNS , GEOCHEMISTRY AND SEDIMENTOLOGICAL IMPLICATIONS
}

\author{
S. Guerzoni \\ Istituto di Geologia Marina, CNR, via Gobetti No. 101, 40129 Bologna, Italy. (E- \\ mail: guerzoni@boigm2.igm.bo.cnr.it) \\ E. Molinaroli \\ Dipartimento Scienze Ambientali, Università, Dorsoduro 2137, 30123 Venezia, \\ Italy (E-mail:molinaro@unive.it) \\ R. Chester \\ Oceanography Laboratories, Dept. of Earth Sciences, P.O. Box 147, Liverpool L69 \\ $3 B X, U K$
}

\begin{abstract}
Data are presented for a number of parameters for aerosols and rainwaters collected at a station on Sardinia. The findings are interpreted with special reference to Saharan dusts, and are compared to other data on these dusts obtained from a variety of sites around the Mediterranean Sea. At the Sardinia site the particle size distribution of the Saharan outbreaks exhibits a bimodal structure, the two modes being between 1 and $2 \mu \mathrm{m}$ and 20-25 $\mu \mathrm{m}$. The presence of giant particles strongly affects the deposition velocities of the Saharan aerosols. Source markers for the Saharan dusts are palygorskite, kaolinite, calcite, dolomite and rounded quartz grains.

The input of Saharan dust has important effects on the chemistry of the Mediterranean aerosols. These include: (i) increases in the atmospheric concentrations and sea surface fluxes of crust-controlled trace metals (e.g.; Al, Fe); (ii) decreases in the EFcrust values of non-crust-controlled trace metals (e.g.; $\mathrm{Cu}, \mathrm{Zn}$ and $\mathrm{Pb}$ ) in the aerosols, and (iii) changes in the solid state speciation of $\mathrm{Cu}, \mathrm{Zn}$, and $\mathrm{Pb}$, which decrease their solubilities in sea water. The Saharan dusts also affect the composition of rainwater by raising the $\mathrm{pH}$, following the dissolution of calcium, and by decreasing the solubility of trace metals such as $\mathrm{Cu}, \mathrm{Zn}$ and $\mathrm{Pb}$.

Wet deposition controls the flux of Saharan dust to the Mediterranean Sea, but dry deposition can also be important. The dust transport occurs in the form of "pulses", and the annual dust flux can be controlled by few episodes of Saharan outbreaks; e.g. sometimes a single outbreak can account for 40-80 \% of the flux. Saharan dust deposition fluxes range from 2 to $25 \mathrm{~g} \mathrm{~m}^{-2}$ (average; $\cong 10$ ) in the W Mediterranean between $39^{\circ}$ and $42^{\circ} \mathrm{N}$, between 6 and $46 \mathrm{~g} \mathrm{~m}^{-2}$ (avg. $\cong 20$ ) in the E Mediterranean, and 0.4 to $1.0 \mathrm{~g} \mathrm{~m}^{-2}$ over the Alps on continental Europe. The present day Saharan dust fluxes $\left(\approx 1 \mathrm{mg} \mathrm{cm}^{-2} \mathrm{yr}^{-1}\right)$ account for about $10-20 \%$ of the recent deep-sea sedimentation in the Western Mediterranean (3-15 $\mathrm{mg} \mathrm{cm}^{-2} \mathrm{yr}^{-1}$ ).
\end{abstract}




\section{INTRODUCTION}

One of the principal aims of the EROS 2000 Project was to gain an understanding of the marine cycles of trace metals in the Western Mediterranean Sea. To achieve this it is necessary to evaluate the relative importance of both fluvial and atmospheric inputs of the metals to the water column.

Atmospheric inputs to the Mediterranean (MED) Sea are of special interest because of the different regions of aerosol production on the northern and southern shores (see e.g.; Gilman and Garrett, 1994). The northern shore of the MED is bordered by industrialised and semi-industrialised regions, which act as a continuous source of anthropogenic-dominated 'background' aerosol, dispersed to the MED atmosphere all year round. In contrast, the MED is bordered on its southern and eastern shores by arid and desert regions, including the Sahara and Middle Eastern deserts. These deserts act as a source of crust-dominated aerosol, which is transported largely in the form of non-continuous dust 'pulses'. In addition, there are inputs of aerosols to the MED atmosphere from the Atlantic Ocean to the west, from the sea surface, and from local volcanic activity. However, two principal sources, i.e. the European anthropogenic source and the desert crustal source, dominate the supply of material to the MED atmosphere, and in the Western and Central MED region the dust inputs are largely from the Saharan region. These inputs have an important influence on both the mineralogical and the trace metal composition of the MED Sea aerosol (Chester et al., 1993a). For example, Bergametti et al., (1989a) concluded that the two major factors controlling variations in particulate trace metal concentrations in Corsica in the Western MED are: (i) precipitation scavenging, which affects both crustal and anthropogenic trace metals, and (ii) the inputs of Saharan dusts, which affects crustal trace metals.

Outbreaks of dust-laden Saharan air over the MED and southern Europe are frequent (Eriksonn, 1979; Ganor and Mamane 1982; Bücher et al., 1983; Bücher, 1989; Löye-Pilot et al., 1986), and episodes of dust haze over Sardinia usually occur several times each year (Prodi and Fea, 1979; Bergametti et al., 1988; Guerzoni et al., 1992a, 1993). Saharan dust has been observed in Alpine snow (Wagenbach and Geis, 1989, De Angelis and Gaudichet, 1991) and has been collected from the atmosphere over the MED (Chester et al., 1984; Tomadin et al., 1984, Correggiari et al., 1989, Molinaroli et al., 1993). A significant Saharan dust component has also been identified in Quaternary marine sediments in parts of the MED (Venkatathnam \& Ryan, 1971; Eriksonn 1979; Tomadin and Lenaz, 1989).

The MED basin is located on the southern margin of Europe and could be amongst the first areas to experience the effects of an eventual increased aridity of the Sahara desert, associated to a northward movement of the climatic belt due to global warming. However little attention has been given to the direct measurements of the relative importance of dry and wet deposition pattern, and very few data, if any, are available at marine coastal sites south of $40^{\circ}$ Lat. $\mathrm{N}$.

Various aspects of the marine aerosol have been considered elsewhere in this volume, and the present paper is limited to the mineral aerosol over the Western and Central MED. In particular, the dissolved/particulate speciation of trace metals in rain waters is discussed in detail by Guieu et al. (1996), and sedimentation rates data are presented by Emelyanov and Zuo (1996) and therefore will not be considered here.

The present study focuses on deposition patterns and source signature of Saharan aerosols, collected concurrently in both dry and wet deposition, during two 
separate periods totalling 12 months in two years (October 1990/September 1992), at a remote site in SE Sardinia (Capo Carbonara, 39 ${ }^{\circ}$ Lat N, $9^{\circ}$ Long E). An attempt to compare Sardinia data with other sites around the MED Sea and to highlight the role of desert dominated dust in the geochemistry and sedimentology of the basin is also presented. Finally, the present-day eolian fluxes are compared to sedimentation rates in the Western MED basin.

\section{METHODS}

\section{Sampling and analytical techniques}

Samples were collected at Capo Carbonara, a remote coastal station in southeastern Sardinia, 3-400 km north of the Saharan desert and more than $400 \mathrm{~km}$ from continental Italy (northeast) and France (northwest) (Fig. 1). Two-three day aerosol samples (dry), and concurrent event-by-event rain samples (wet) were collected. A total of 131 samples were collected in the period Oct. '90/Oct. '92, 100 of which were aerosols and 31 rain episodes. In particular, aerosol sampling covered two distinct periods: 1/10/1990-30/4/1991 and 1/5-30/09/1992, while precipitation was collected continuously in the period 1/10/1990-30/09/1991. The second aerosol period was added to fill the gap of summer sampling during 1991, and will be treated together with the rest of the data due to the similarity between 1991 and 1992 annual and summer precipitations at Capo Carbonara (average annual precipitatation=305 and 290 $\mathrm{mm}$, respectively; average summer precip $=30$ and $20 \mathrm{~mm}$ ). The sampling methodology, sample treatment and analytical details are described elsewhere (Guerzoni et al. 1987, 1992; Molinaroli et al., 1993), and are summarized in the Appendix. Only part of the aerosol samples (55 over 100) were analysed for trace metals.

In addition, as part of the EROS-2000 programme, long-term particulate trace metal collections were carried out at a series of sites in Western/Central MED Sea (Fig. 1). The sites were: Blanes (a coastal site in southern Spain), Cap Ferrat and Tour du Valat (coastal sites in southern France) and Sardinia (an island site in the Central MED). Particulate trace metal data for these sites, together with those reported by Bergametti et al., (1989) for Corsica and Kubilay et al. (1994) for Erdemli, a site on the eastern coast of Turkey, will be discussed in trace metal session.

\section{RESULTS AND DISCUSSION}

\section{TRANSPORT FROM THE SAHARA OVER THE MED SEA AND TO EUROPE}

\section{Source areas for airborne Saharan dust}

A dust reservoir several $\mathrm{km}$ thick is continuously produced over the Sahara and transported across the desert margins. However Schütz (1989) noticed no continuous flow of dust over the MED and Europe. Several distinct source areas are thought to be productive in the Sahara. In order to compute production and deposition rates of the dust emerging from the desert area over two years (1981-82), D' Almeida (1986) selected the most productive source areas for his box-model (Fig. 1). He estimated a total mass production of approximately 700 million tons; about $60 \%$ of the mass 
moves southward to the Gulf of Guinea and less than $30 \%$ is transported across the northern equatorial Atlantic Ocean to the Caribbean Sea. The present authors computed the monthly northern components of the dust transport (plotted in Fig. 2), showing that Saharan dust transport to Europe is sporadic in nature. It often occurs in summer and mainly originates from sources 2 and 1. Dust transport across the northern borders of the Sahara into the MED and to Europe is approximately $12 \%$ of the total, i.e. $\sim 100$ million tons $(\sim 13$ of which $<5 \mu \mathrm{m})$. These estimates are subject to severe uncertainities in relation to large scale meteorological features (dry years, ITCZ latitudinal position) which determine strong interannual variabilities. While most of the indirect measurements (model, meteosat, AVHRR) show that the transport peaks in summer (Dulac et al., 1992, 1995; Lambert et al., 1995), the direct measurements (mainly bulk deposition, Loÿe-Pilot et al., 1995, Le Bolloch and Guerzoni, 1995) and the historical inventories of occurence of dust rain or dust haze in Europe (e.g. Bücher 1989) indicate maximum fallout in spring and autumn.

\section{Measurements in air and rain}

Recently Correggiari et al. (1989), Molinaroli et al (1993), and Guerzoni et al. (1995 a,b) reported on data collected in Sardinia, the most southerly station available in the Western MED. We present here (Table 1) average concentrations of mineral dust in air (MSP) and particles in rain (TPC), subdividing the samples into "background" (non-Saharan) and "Saharan". In Fig. 2 MSP and TPC values are plotted versus sampling date.

Even when a reasonable estimate of the trace metal composition of the Saharan material is available, it is still difficult to de-couple the desert-derived "endmember" aerosol from the "background" component at sites that are relatively close to pollution sources. However, two approaches can be adopted to achieve this. One is the use of air-mass back trajectories to define source regions (Harris et al., 1982). The second approach utilises the fact that much of the Saharan dust over the MED Sea is transported in the form of "pulses", and the identification of these "pulses" offers a potential way of isolating the desert-derived component. For this purpose, Chester et al., (1995a) made an arbitrary assumption, based on dust "spike" over background ratio, that a particulate $\mathrm{Al}$ concentration $>10^{3} \mathrm{ng} \mathrm{m}-3$ of air represents the input of desert-derived dust "pulse" at any site in the MED Sea. Similarly, Dulac et al. (1987) selected a slightly lower particulate $\mathrm{Al}$ concentration (> $\left.0.5 \times 10^{3} \mathrm{ng} \mathrm{m}-3\right)$, to separate crust-enriched and background populations in ship samples collected across the Western MED. Other combined criteria which could be used to classify background and Saharan aerosols include the use of mineralogical markers, Al/Si ratio and $\mathrm{Ca}$ content (Molinaroli et al., 1993). Al/Si ratio has been used by Bergametti et al. (1989b) to recognize different source provenances within the Africa continent. We were not able to make this distinction, but an $\mathrm{Al} / \mathrm{Si}$ ratio higher than 0.3 was always indicative of desert origin of the particles. For precipitation, $\mathrm{pH}$ values were also used to improve classification, since the alkalinization effect of Saharan dust in rain has been well described, both in Sardinia (Caboi et al., 1991, Le Bolloch and Guerzoni, 1995) and elsewhere (Löye-Pilot et al., 1986, Glavas 1988, Roda et al., 1993).

From Table 1 it is evident that approximately $2 / 3$ of the dry and $1 / 2$ of the rain episodes sampled did not include a Saharan contribution. The MSP data confirm previous work, that shows average background dust concentrations in the Western MED between 2 and $4 \mu \mathrm{g} \mathrm{m} \mathrm{m}^{-3}$. In particular, Bergametti (1989a,b) registered 
background $\mathrm{Al}$ values in Corsica equivalent to 2-3 $\mu \mathrm{g} \mathrm{m}^{-3}$ of particles; Prospero (1981) reports geometric means for mineral aerosols in the MED Sea of $4 \mu \mathrm{g} \mathrm{m}^{-3}$, and Chester (1984) approximately $2 \mu \mathrm{g} \mathrm{m}^{-3}$.

The crust-enriched group in Tab. 1 represents samples with some crustal enrichment of Saharan provenance, mixed with other contributions often not identified. The aerosols in this group have MSP values twice the background values, and the rain samples have $\mathrm{pH}$ values between 5.6 and 6.0. We have included this group in the computation of the desert contribution, and this could could be a source of uncertainty, even if we can exclude any significant local contribution. The Saharan group also highlights the "outbreaks", i.e. the biggest direct transport events. For trace metal discussion (see below), only "pure" Saharan and the "outbreaks" events will be used for comparison with other crust-dominated aerosols collected in the MED area.

The high variability of MSP concentrations in air, accounted for by the desertenriched episodes collected in Sardinia, can be seen in Figure 2. A clear seasonal trend is visible, with all winter sample values around the background level, and spring/summer samples mainly crust-enriched. Guerzoni et al. (1995a) have demonstrated the influence of precipitation on the MSP concentration: in fact, a 30\% increase in mineral particulate background levels was detected after more than 3 rainless days. Similarly, Remoudaki et al. (1991) observed that frequency of precipitation in Corsica gave rise to a seasonal cycle of atmospheric particulate concentrations: being 2-3 times higher during the dry season than during the rainy season. Superimposed on this pattern there were sporadic emissions of crustal substances, characterized by a variable intensity without any seasonal pattern. The number of crust-enriched episodes at Sardinia in the study period (40 $\left.\mathrm{yr}^{-1}\right)$ is higher than that found in Corsica by Bergametti et al. (1989a) of 20 events $\mathrm{yr}^{-1}$, whilst the two strong episodes of Saharan dust outbreaks agree with the 2-4 outbreaks yearly recorded by Prodi and Fea (1979).

Total particulate content values (TPC) are also highly variable, with half of the samples classified as background (GM $\left.<1 \mathrm{mg} \mathrm{l}^{-1}\right)$ and two red dusts with the highest TPC content $\left(\mathrm{GM}=263 \mathrm{mg} \mathrm{l}^{-1}\right)$. Within the rainy season (Oct-Apr) no specific pattern was observed.

\section{Meteo conditions}

The transport of desert-dominated aerosols is related to the position of the sub-tropical anticyclone over the NE Atlantic and to the presence of polar air-masses over both the Atlantic Ocean and the European continent. The prevailing conditions determining dust transport towards the MED are: (i) a depression over Spain (50\% of cases); (ii) a depression over North Africa (25\%), and, (ii) an anticylone over the MED (Lambert et al., 1995). Differences are found between the western and eastern part of the basin, both in terms of seasonallity and duration of transport. For instance, Dayan et al. (1991) studied several dust intrusion events into the MED, and demonstrated that in the western part the transport of Saharan, dust usually occurs in a deeper atmospheric layer for a longer duration than eastern MED dust events. For the western part they estimated a weekly averaged optical depth corresponding to about 50-80 $\mu \mathrm{g} \mathrm{m}^{-3}$ over a 2-4 day/event.

Figure 1 shows the different possible routes of Saharan dust transport, as studied by different authors, in occasion of dust outbreaks. Among them, Prodi \& Fea (1979), Bergametti et al. (1989b), and Gilman and Garret (1994) highlighted the 
conditions favouring dust transport to Western and central MED, and Ganor and Mamane (1982) to the Eastern MED, through "Mediterranean" routes, and Reiff et al. (1986) studied an African event reaching NW Europe through an "Atlantic" route. However, sometimes "Mediterranean" trajectories can carry a great quantity of dust to Northern Europe (see, e.g. Franzen et al, 1994).

\section{Atmospheric deposition: dry and wet modes}

In the Western MED and in the case of Saharan deposition studies, it is apparent that different seasonal cycles must be taken into account when considering both wet and dry patterns. The continuous analyses of dry and wet deposition in Sardinia showed that approximately $3 / 4$ of the Saharan dust is deposited with precipitation (Guerzoni et al., 1992a). This result has been documented in Corsica by Bergametti et al. (1989a) and Loÿe-Pilot et al. (1989). For the aerosols a simple model was presented by Molinaroli et al (1993), where it was shown that crust-enriched aerosol concentrations are latitudinally controlled. If aerosol values (and associated dry deposition) are generally higher during the hot season, the transfer to the ground is more significant in spring (and autumn).

The total atmospheric deposition of particles measured in Sardinia, that was more than $1300 \mu \mathrm{g} \mathrm{cm}^{-2}$ on an annual basis (Guerzoni et al., 1995a), has been divided into "background" and "Saharan" components using the previously described criteria. The "Saharan" component resulted to be $1100 \mu \mathrm{g} \mathrm{cm}^{-2}\left(250 \mu \mathrm{g} \mathrm{cm}^{-2}\right.$ dry and $850 \mu \mathrm{g}$ $\mathrm{cm}^{-2}$ wet ). The monthly dry flux data, as sums of at least ten 3-days aerosol samples; and the monthly wet fluxes, were both calculated for the period October 1990-April 1991 and May-October 1992, according to the equation given in the Appendix (Figure $3)$.

It is apparent that the wet mode prevails largely over the dry one, and that a few episodes account for most of the particles fluxes. Particulate fluxes in Sardinia show a marked annual variability; $581 \mu \mathrm{g} \mathrm{cm}-2$ for one wet episode accounting for more than $60 \%$ of the total annual flux in '90/91. Le Bolloch and Guerzoni (1995) have shown that the same occurred in Sardinia in another period (1992/93), where $208 \mu \mathrm{g}$ $\mathrm{cm}^{-2}$ for three events accounted for $80 \%$ of the flux, even though a decrease in the wet flux was noted for this year. The same authors presented data from another station on western Sardinia, where a strong inter- as well intra-annual variability in dust fluxes was recorded.

If we look at a more long-term record, such as that of Bücher (1989), we can see that both present fluxes and the dust fallout (Fig. 3, curve A) peak in February/March and October/November, in close correlation with the wet seasons. Very low deposition rates are recorded during the summer; apart from the scarcity of precipitation during this period in the MED, several reasons seem to prevent high deposition in summer, despite the high emission frequencies (Fig. 3, curve B), including (i) the gradient between warm air and cold fronts, usually associated with outbreaks (Dayan et al., 1995), and (ii) upward dust movement, which determines much lower real dust deposition than expected by grain-size data and model calculations (Dulac, 1995).

For the wet components, during the sampling period a single episode provided more than $70 \%$ of the total wet flux. Loÿe-Pilot et al. (1989) found a similar pattern in Corsica, with several episodes accounting for 20 to $70 \%$ of the annual particle flux. Furthermore, no apparent correlation between rainfall and particulate input at one 
given site was observed. This is also the case for Sardinia, where the amount of particulates is independent of the amount of precipitation (Table 1).

The deposition of dry particles is not always related only to the amount of precipitation. In cases of long ( $>10$ days) crust-enriched episodes other mechanisms can occur. In fact, for the aerosols concentrations and precipitation fluxes in October 1990 (Fig. 2) we can follow 5 consecutive 3-day periods of crust-enriched aerosol samples (values listed in Tab.2). During this period, 5 rain events also occurred, and these events affected aerosol concentrations only in the first part of the period ( 6 days). In the second part, high values of aerosol after two precipitation events can still be seen. This yields a higher wet deposition, compared to dry, in the first period, but a higher contribution of dry over wet deposition for the second one, even when preceded by rain events. In fact, while comparable particle fluxes were observed during the first deposition period ( $17 \mu \mathrm{g} \mathrm{cm}^{-2}$ dry and $20 \mu \mathrm{g} \mathrm{cm}^{-2}$ wet), the dry deposition was almost three times higher than the wet one $\left(45 \mu \mathrm{g} \mathrm{cm}^{-2}\right.$ dry and $17 \mu \mathrm{g} \mathrm{cm}^{-2}$ wet $)$ during the second period, despite several rain events before and during it (Table 2). Similarly, during a twelve days study of a Saharan outbreak in June/July 1985, Dulac et al. (1989) found that either in the first period the wet deposition was more efficient than dry deposition of $\mathrm{Si}$ (a crustal element), or that a considerable dry deposition of this element occurred immediately after a rainy period.

\section{Volume particle-size distribution in Saharan dust}

Large particles play a major role in controlling the dry deposition of mineral particles. In particular, aerosol particles with diameters of $10 \mu \mathrm{m}$ or greater dominate the dry deposition flux. In Sardinia, Molinaroli et al. (1993) observed that dry aerosols consist mainly of silty-clay or clayey-silts, with particle size diameters ranging from 0.2 to $102 \mu \mathrm{m}$. A clear distinction between grain-size in background and Saharan samples has been observed. In particular, background samples have a monomodal distribution with the highest clay content and a mode centred at $1 \mu \mathrm{m}$, while Saharan dust showed a bimodal distribution.

The Saharan outbreaks (dry depositional mode), analysed in the present study, generally show a bimodal structure. Such a structure has been shown by Prodi and Fea (1979) and by D' Almeida and Schütz (1983), to be characteristic of aerosols from the Sahara. The dust particle diameters during Saharan "dry" outbreaks collected in Sardinia, range from 0.2 to $102 \mu \mathrm{m}$ (Fig. 4A); for October 1990 there were two modes, with maximum concentrations between $3-4 \mu \mathrm{m}$, and $50 \mu \mathrm{m}$ in diameter, the latter having highly variable concentrations. For the March 1991 outbreak, the two modes werebetween $1-1.26 \mu \mathrm{m}$, and $13-16 \mu \mathrm{m}$ in diameter. Particle size distribution of two Saharan "wet" outbreaks collected at the Sardinia station in March 1992 and October 1993 showed modes at $8 \mu \mathrm{m}$ and $25-30 \mu \mathrm{m}$ in diameter for the first and a single mode between 20 and $40 \mu \mathrm{m}$ for the second, with a tail towards the finest particles. It is apparent from the plots in Fig. 4 that the two wet aerosols were enriched in large particles compared to dry aerosol outbreaks. It therefore seems reasonable to attribute differences in the size distributions of the Saharan outbreaks collected in Sardinia to different transport mode (dry and wet), which, in turn, are related to different transport velocities and lengths of airborne trajectories.

To evaluate and characterise the Saharan outbreaks in the MED area, distinct episodes of Saharan dust (dry and wet) are reported for different land-based stations in 
Europe. It must be emphasised that the data from other authors were collected at different times and with different methods and thus cannot be directly compared. Franzen et al. (1994) described that for the same March 1991 dustfall with snow in northern Fennoscandia, the particle size distribution ranged from $0.9-6.8 \mu \mathrm{m}$ with a median value at $2.7 \mu \mathrm{m}$. Guerzoni et al., (1992b) measured mass particle size distributions from rain and aerosol Saharan outbreaks in Sardinia; the median was about $15 \mu \mathrm{m}$ in two different rain samples with the presence of two modes (3 and $15 \mu \mathrm{m})$ in one aerosol sample. Dessens and Van Dinh (1990) measured particle size distribution of a Saharan dust collected in precipitation in the northern Pyrenees (France). The dust particle diameters ranged from about $1 \mu \mathrm{m}$ to $100 \mu \mathrm{m}$, with a median volume diameter of $8 \mu \mathrm{m}$ and a maximum concentration at about $10 \mu \mathrm{m}$. Littmann et al. (1990) reported the results of several Saharan deposition events (dry) in Bochum, West Germany with a very high variability of the median volume diameter between 2.2 and $16.1 \mu \mathrm{m}$. Tschiersch et al., (1990) measured a volume size distribution of Saharan dust in snow from the High Alpine Station (3450 m above sea level), Jungfraujoch, Switzerland. They showed particle size distribution between 1 and $4 \mu \mathrm{m}$, with a mode at about $4 \mu \mathrm{m}$. A decrease of the MMD of $\mathrm{Al}$ from $\sim 4 \mu \mathrm{m}$ to $\sim 2 \mu \mathrm{m}$, during the transport of mineral aerosol from Africa over the MED Sea was also observed by Dulac et al. (1989).

In conclusion, the particle size distribution in the Saharan outbreaks exhibits no clear relationship between median, modality or transport distance. With respect to long range transport, grain size fractionation is not a clear function of aerosol sedimentation velocity, and factors other than gravitation and turbulence may play an important role. Nevertheless, the presence of giant particles is common and explains the wide range of deposition velocities associated with desert-rich aerosols found by different authors. This can also explain the high uncertainties, up to one order of magnitude, in flux calculations and estimates, such as those found in Corsica by Dulac et al. (1989), who measured average deposition values for $\mathrm{Al}$ (indicative of desert dust) of $\approx 3 \mathrm{~cm} \mathrm{~s}^{-1}$, with a range between 1 and $7 \mathrm{~cm} \mathrm{~s}^{-1}$.

CONTRIBUTION OF MINERAL DUST TO THE ATMOSPHERE AND OCEANS ON A BASIN SCALE: TRACE METALS AND MINERALOGY

\section{Trace metal Composition of the Saharan aerosols and rainwaters}

On initial observation, the Mediterranean aerosol can be considered to consist of a continuously supplied, European-derived, anthropogenic-dominated "background" material, which is perturbed by intermittent injections of crust-dominated, Saharan dust "pulses". The degree to which a trace metal in an aerosol or rainwater is enriched, or depleted, relative to the crustal source can be assessed by using an enrichment factor $\left(\mathrm{EF}_{\text {crust }}\right)$-see Appendix. $\mathrm{EF}_{\text {crust }}$ values may therefore be used to distinguish between elements associated with the two major aerosol components in the MED aerosol; i.e. those having a predominantly crustal source (non-enriched elements, NEEs) and those having a mainly anthropogenic source (anomalously enriched elements AEEs).

The trace metal composition of "pure" Saharan dust of the type transported over the MED Sea can be obtained from Saharan-derived samples collected from the Atlantic northeast trades far from the major pollution sources. Average trace metal concentration and $\mathrm{EF}_{\text {crust }}$ data for a series of these dusts are given in Table 3, from 
which it can be seen that all the trace metals have $\mathrm{EF}_{\text {crust }}$ values $<10$. This may therefore be considered to represent the Saharan "end-member" aerosol injected into the MED atmosphere. Average trace metal and $\mathrm{EF}_{\text {crust }}$ data for aerosols collected at a number of sites on the northern shore of the MED Sea are given in Table 4. However, it is difficult to assess the effects that Saharan dusts have on the MED aerosols collected at individual sites, because this will depend on a number of complex interrelated factors. These include; (i) the magnitude and frequency of Saharan dust outbreaks, (ii) the distance from the continental dust source regions, and (iii) the concentrations of European "background" material in the air (e.g., Chester et al., 1995a). All these factors vary both spatially and temporally, and because the samples from the various sites were collected at different times, it must be stressed that the data in Table 4 should be regarded as giving no more than an indication of the trace metal concentrations to be expected in the atmosphere of the MED Sea. However, although these are average data, the important point is that at all the sites there was evidence of the input of Saharan dust "pulses" (for individual sites refer to reference given in Table 4, and for locations refer to Figure 1). For example, at the Corsican site 20 Saharan dust events were recorded during the collection period. By assuming that $\mathrm{Al}$ concentrations $>10^{3} \mathrm{ng} \mathrm{m}^{-3}$ of air represent a Saharan dust event (e.g., Chester et al., 1995a), the effect that the Saharan material has on the total aerosol population can be assessed for the samples collected in Sardinia. On this basis, the Sardinian samples have been divided into two groups; a Saharan group, $\mathrm{Al}>10^{3} \mathrm{ng} \mathrm{m}^{-3}$, and a nonSaharan group, $\mathrm{Al}<10^{3} \mathrm{ng} \mathrm{m}^{-3}$ of air. The average trace metal data for both groups are given in Table 5, from which it is apparent that the input of Saharan dust results in increases in the total concentrations of the NEEs, such as $\mathrm{Al}$ and $\mathrm{Fe}$, and in decreases in the $\mathrm{EF}_{\text {crust }}$ values of AEEs, such as $\mathrm{Cu}, \mathrm{Zn}$ and $\mathrm{Pb}$. The overall effect of Saharan dust inputs is therefore to drag the composition of the total aerosol towards that of primary crustal material. The effects these Saharan inputs have on marine biogeochemical cycles in the MED Sea, following the deposition of the dust to the mixed layer, are considered below.

The magnitude of air to sea trace metal fluxes is dependent on the concentrations of the metals in the air. However, the subsequent fate of the metals in the marine environment is strongly influenced by two additional factors: (i) the solid state speciation of the metals in the parent aerosol, and (ii) the process by which the aerosols are removed from the air.

(i) The solid state speciation of trace metals in aerosols. Chester et al. (1989) carried out solid state speciation studies on a series of trace metals in crust-dominated and anthropogenic-dominated "end-member" aerosols. The technique used separates three aerosol trace metal binding associations; an exchangeable association, an oxide/carbonate association, and a refractory association. In this classification, trace metals in the exchangeable association are potentially the most environmentally mobile in natural waters, and those in the refractory associations are the least mobile.

The results obtained by Chester et al. (1989) may be summarised as follows. (a) Aluminium and $\mathrm{Fe}$ are generally refractory in both the crustal and the anthropogenic "end-member" aerosols. (b) Manganese is speciated between all three associations in both "end-member" aerosols. (c) Copper, $\mathrm{Zn}$ and $\mathrm{Pb}$ have very different speciation signatures in the two aerosols. In the crustal "end-member" $65 \%$ of the total $\mathrm{Pb}(\mathrm{Pb}), 75 \%$ of the $\mathrm{Cu}$ and $90 \%$ of the $\mathrm{Zn}$ are found in refractory fractions. In contrast, in the anthropogenic 'end-member', $50 \%$ of the $\mathrm{Cu}$, and $90 \%$ of the $\mathrm{Zn}$ and the $\mathrm{Pb}$ are in exchangeable associations. Clearly, therefore, there are important 
differences in the manner in which some trace metals are partitioned between the components of crustal and anthropogenic aerosols, and these will affect the chemical character of the total MED Sea aerosol when it is perturbed by Saharan inputs. Further, the solid state speciation differences between crustal and anthropogenic aerosols will play a critical role in constraining the fates of the trace metals in the marine environment. The reason for this is that the manner in which trace metals enter the major marine biogeochemical cycles is largely constrained by the extent to which they are soluble in sea water, which, in turn, is a function of their solid state speciation.

(ii) The processes by which the aerosols are removed from the air. Aerosols are removed from the atmosphere by a combination of "dry" (i.e. not involving aqueous phase) and "wet" (precipitation scavenging) depositional modes. These two depositional modes are geochemically different with respect to the solution with which the aerosols initially come into contact.

In the "dry" mode aerosols are delivered directly to the sea surface by airsea route and trace metal solubility is constrained by aerosol $\leftrightarrow$ sea water reactions. Chester et al. (1993b) carried out a study on the factors that control the solubility of trace metals from non-remote crust-dominated and anthropogenic-dominated aerosols following their "dry" deposition to the sea surface. The authors found a well-developed relationship between the extent to which a trace metal is partitioned into exchangeable binding associations in the aerosol and the extent to which it is soluble in sea water. With respect to the MED aerosol, the most important finding was that $\mathrm{Cu}, \mathrm{Zn}$ and $\mathrm{Pb}$ are considerably more soluble from the anthropogenic-dominated $(\sim 25 \%$ of the $\Sigma \mathrm{Cu}$, $\sim 70 \%$ of the $\Sigma \mathrm{Zn}$ and $\sim 40 \%$ of the $\Sigma \mathrm{Pb}$ ) than from the crust-dominated aerosol ( $15 \%$ of the $\Sigma \mathrm{Cu}, \sim 30 \%$ of the $\Sigma \mathrm{Zn}$ and $\sim 15 \%$ of the $\Sigma \mathrm{Pb}$ ), which reflects the differences in their exchangeable/refractory speciation signatures in the two aerosol types. It may be concluded, therefore, that the sea water solubilities of the $\mathrm{Cu}, \mathrm{Zn}$ and $\mathrm{Pb}$ from aerosols deposited to the sea surface by the "dry" deposition mode will be considerably reduced during Saharan dust events. In fact, Chester et al. (1993b) suggested that following their deposition to the sea surface Saharan dust can act as sinks rather than sources, for dissolved $\mathrm{Cu}, \mathrm{Zn}$ and $\mathrm{Pb}$ by providing scavenging surfaces. However, by increasing the concentrations of NEEs in the atmosphere, and therefore the magnitude of the air to sea flux, the injection of Saharan dusts can increase the amounts of metals such as $\mathrm{Al}$ and Fe added to the dissolved sea water pool, even though their overall solubility is relatively low.

In "wet" deposition mode aerosols reach the sea surface by the indirect airrain watersea water route, following in-cloud or below-cloud precipitation scavenging processes. Trace metal solubility in the "wet" deposition mode is therefore initially constrained by aerosol $\leftrightarrow$ rain water reactions. The total trace metal concentrations (i.e. dissolved + particulate) in rainwaters reflect those in the scavenged aerosols. However, the dissolved/particulate speciation of the metals is a function of the rain water chemistry, especially the solution $\mathrm{pH}$. Loÿe-Pilot et al. (1986) showed that the $\mathrm{pH}$ of Western MED rainwater is strongly affected by the type of material scavenged from the air; with the scavenging of anthropogenic material giving rise to $\mathrm{pH}$ values in the range $4.0-5.5$, and the scavenging of Saharan dust, giving rise to $\mathrm{pH}$ values as high as $6-7$ because of the dissolution of calcium carbonate from the desert-derived material. The type of aerosol scavenged from the air also affects the trace metal chemistry of rainwaters. This can be illustrated with respect to two examples of rainwaters collected at Cap Ferrat; one of which scavenged European anthropogenic-dominated material from the air, and the other of which scavenged Saharan dust. Data for the two samples 
are given in Table 6, from which four principal trends can be identified, (i) the $\mathrm{pH}$ of the rainwater that has scavenged Saharan dust (6.55) is higher than that in the rainwater that has scavenged the anthropogenic-dominated aerosol (3.96), (ii) the concentration of $\mathrm{Al}$, the crustal indicator element, is an order of magnitude greater in the rainwater that has scavenged Saharan dust, (iii) the $\mathrm{EF}_{\text {crust }}$ value for $\mathrm{Cu}$ is an order of magnitude higher, and that for $\mathrm{Pb}$ is two orders of magnitude higher in the rainwater that has scavenged the anthropogenic-dominated aerosol, and (iv) $\mathrm{Cu}$ and $\mathrm{Pb}$ are considerably more soluble in the rainwater that has scavenged the anthropogenicdominated than the Saharan aerosol.

\section{Mineralogical composition of the Saharan aerosol}

Aerosols and rains collected during the Saharan events reaching Sardinia have been analysed for mineralogical composition in order to highlight the contribution made by dusts to sedimentation in the MED Basin. The following mineral assemblage was found in all the aerosols: quartz, calcite, feldspars, dolomite, illite, kaolinite, chlorite, smectite and palygorskite. In two Saharan outbreaks collected in Sardinia (Fig. 5) quartz is the most abundant mineral; it has a round shape and is found over a wide range of particle sizes $(1-40 \mu \mathrm{m})$. Illite is the predominant clay (42\% to $54 \%$ ), and kaolinite (25\% to $35 \%$ ) exceeds chlorite ( $8 \%$ to $10 \%)$ ( $\mathrm{K} / \mathrm{C}$ is always $>2)$; the latter ratio being indicative of a desert origin (Mazzucotelli et al., 1984). Palygorskite and dolomite have been used as tracer minerals for desert-derived dusts (Robert and Gauthier, 1989; Coudé-Gaussen et al., 1987). Of special interest is the fact that palygorskite was found only in the silt fraction of the dust collected at Sardinia, but was absent from the clay fraction. The presence of palygorskite was confirmed by SEM-EDS analysis, which revealed that it was present as particles ranging in size between 6 and $40 \mu \mathrm{m}$. The mineral occurs in three minerals associations: (i) as windshaped grains with felt-like surface texture, (ii) as interwoven fibrous mats forming fine laminae, and (iii) and as pore filling and pore-bridging cements that coat and occur between, detrital grains of calcite, dolomite etc. (Molinaroli and Ibba, in press). Dolomite frequently showed weathering voids; calcite grains, in contrast, were sometimes found well preserved.

Clay minerals have the potential to act as "source tracers" for material transported into the region. In Fig. 6 comparisons are made between the clay mineralogy of series of Sahara and background dusts from the MED atmosphere, and between the dusts and sediments from the MED Sea. A number of overall conclusions can be drawn from those data.

(1) There is a general agreement between the clay mineral compositions of the Saharan dusts: i.e. those collected in Sardinia (Fig. 6.1), in the Tyrrhenian Sea (Fig. 6.2), and during the BAN 80 cruise (Fig. 6.3). These dusts have relatively high concentrations of illite, more kaolinite than chlorite, and variable amounts of smectites. The clay composition of desert-derived dusts collected in the Eastern MED (Fig. 6.4) also has more kaolinite than chlorite, but in these dusts kaolinite also exceeds illite.

(2) Dusts that contain a significant European "background" component (Fig. 6.5-6 and 7) contain no smectite, considerably more illite than kaolinite, and approximately similar proportions of kaolinite and chlorite.

(3) Deep-sea sediments from the Tyrrhenian Sea (Fig. 6.9) and the Adriatic Sea (Fig. 6.11) have clay mineral signatures similar to those of the Saharan dusts. Chester et al. 
(1977) have shown that Saharan dusts make an important contribution to certain deepsea sediments in the Eastern MED Sea. Over the entire Eastern MED, however, the deep-sea sediments contain considerably higher quantities of smectites (Venkatarathnan and Ryan, 1971) than the Saharan dusts, mainly as the result of an input from the Nile. However, with the blocking of the Nile by the Aswan dam, Saharan dusts will make a larger contribution to the deep-sea sediments of Eastern MED than they have in the past.

It may be concluded that Saharan dusts are an important sediment-forming component of deep-sea sediments of the Southern Tyrrhenian Sea and the Southern Adriatic Sea. This is in agreement to the findings of Correggiari et al., (1989) who suggested a possible regional "signature" of the atmospheric crustal (Saharan) contribution in marine deep sediments of Tyrrhenian Sea and Sicily Channel.

\section{Saharan contribution to sedimentation}

If we try to make even a rough estimate of present-day Saharan dust deposition fluxes around the MED we will see both a great site-to-site and interannual variability. Long-term direct measurements in Sardinia (Guerzoni et al., 1993; 1995a), Corsica (Loÿe-Pilot et al., 1986; Bergametti at al., 1989) and Crete (Nihlen and Mattsson, 1989; Pye, 1992) (Table 7) show fluxes ranging from 2 to $25 \mathrm{~g} \mathrm{~m}^{-2}$ (avg. $\cong 10$ ) in the W MED, between $39^{\circ}$ and $42^{\circ}$ Lat $\mathrm{N}$, and between 6 and $46 \mathrm{~g} \mathrm{~m}^{-2}(\operatorname{avg} . \cong 20)$ in the Eastern basin (between $34^{\circ}$ and $40^{\circ}$ Lat N). Recently De Angelis and Gaudichet (1991) drew attention to the presence of dust from North Africa in long ice cores drilled at Mount Blanc, and measured an average flux of $1 \mathrm{~g} \mathrm{~m}^{-2}$ for the last 30 years. Wagenbach and Geis (1989) measured a lower but comparable value of $0.4 \mathrm{~g} \mathrm{~m}^{-2}$, at another site in the Alps, as average value for the last 40 years.

Rea (1994) recently showed that, on a global scale, the annual dust loading is of the order of $0.20-0.25 \mathrm{mg} \mathrm{cm}^{-2} \mathrm{yr}^{-1}$ for the whole ocean. He compared these values with eolian dust preserved in deep sea sediments of the Pacific and Atlantic oceans, and demonstrated that downwind from important source regions, this value is exceeded by a factor of 4-5. No data were presented in that paper for the MED Sea,but the MED values seem to be well in agreement with the increment proposed by Rea (1994), near important source regions like the Sahara desert is for the MED basin. We try therefore to compare actual flux data, measured in the Western/Central MED, with bulk sedimentation rates available from the same area.

We have listed in Table 8 sedimentation rates around the basin, that are discussed in other part of this volume (Zuo et al.; Emelyanov, this issue), together with some other published data (Stanley et al., 1980; Mongardi et al., 1994). Despite having been calculated by different authors over different parts of the MED basin, and with different time scales (from recent to Holocene), average sedimentation rates cluster in the range 3-9 mg cm-2 $\mathrm{yr}^{-1}$ for the western side and between 5 and $15 \mathrm{mg}$ $\mathrm{cm}^{-2} \mathrm{yr}^{-1}$, for the Tyrrhenian Sea. As prevoiusly calculated the eolian contribution represents between 10 and $20 \%$.

\section{Future trends}

Recently De Angelis and Gaudichet (1991) pointed out that the desert source has increased in strength since the early 1970's. Dessens and Van Dihn (1990) have also claimed that the frequency of Saharan dust outbreaks has increased slightly in the last decade north of the Pyrenees in southern France. However, no increase in Saharan 
outbreaks was detected in Sardinia over a five-year study period (Le Bolloch and Guerzoni, 1995), and even a slight decrease is shown by Loÿe-Pilot et al. (1995) in Corsica.

An increase in warming leading to further desertification would however cause an increase in the generation of crust-derived Saharan aerosols and a perturbation of the urban aerosol/crustal ratio in MED aerosols. It is not possible, however, to predict the result of these changes in deposited aerosols because of the lack of a regional model for particle deposition (wet and dry), which could consider the modification of the wind pattern on a MED scale, following global climate changes and accompanying feedback mechanisms.

\section{CONCLUSIONS}

Comparing data obtained in Sardinia with a number of Saharan dust parameters no clear latitudinal patterns emerge for the overall deposition of Saharan dust. For example, although there is some evidence for a northward decrease in the dry deposition of the dust, i.e. with increasing distance from the primary Saharan sources, there is no such trend in the wet deposition. The wet deposition that dominates the flux of Saharan dust to the MED Sea, is controlled by the frequency of precipitation rather than atmospheric concentrations of Saharan dust. However, this overall control can be modified by the input of Saharan dust pulses, which can result in dry deposition exceeding wet deposition at certain times. The annual dust flux can be controlled by a few episodes of Saharan outbreaks; sometimes a single outbreak can account for more than $\sim 50 \%$ of the total Saharan dust flux.

The wet and dry mode particle size distributions of Saharan outbreaks collected at Sardinia range from 0.2 to $102 \mu \mathrm{m}$. A bimodal structure was observed for the dry mode, but this was not always apparent for the wet mode. Individual episodes of total Saharan dust (i.e. wet + dry deposition) at different land-based stations in Europe exhibit no clear relationship between median particle size, modality and transport distance from the primary desert source.

Mineralogical source markers for the Saharan dusts are palygorskite, kaolinite, calcite, dolomite and rounded quartz grains. Of special interest is the fact that palygorskite was found only in the silt fraction of the dusts, and that dusts with a significant European "background" component do not contain smectite. Comparison with the mineralogical content of deep-sea sediments reveals that, Saharan dusts are an important sediment-forming component in the Southern Tyrrhenian Sea and the Southern Adriatic Sea.

The input of Saharan dust has important effects on the chemistry of the Mediterranean aerosols. These include: (i) increases in the atmospheric concentrations and air to sea fluxes of crust-controlled trace metals (e.g.; Al, Fe); (ii) decreases in the EFcrust values of non-crust-controlled trace metals (e.g.; $\mathrm{Cu}, \mathrm{Zn}$ and $\mathrm{Pb}$ ) in the aerosols, (iii) changes in the solid state speciation of $\mathrm{Cu}, \mathrm{Zn}$, and $\mathrm{Pb}$, which decrease their solubilities in sea water. The Saharan dusts also affect the composition of rainwater by raising the $\mathrm{pH}$, following the dissolution of calcium, and by decreasing the solubility of trace metals such as $\mathrm{Cu}, \mathrm{Zn}$ and $\mathrm{Pb}$.

The increase in the air to sea fluxes of $\mathrm{Al}$ and Fe during Saharan dust outbreaks can have important biogeochemical consequences. The reason for this is that although both metals generally have low solubilities from Saharan dusts, they are present in 
relatively high concentrations in desert-derived material. As a result, a solubility of only a few per cent can led to the addition of large quantities of $\mathrm{Al}$ and $\mathrm{Fe}$ to the dissolved sea water pool; this is especially important for Fe, which is thought to play a key role in primary production.

Average present-day Saharan dust fluxes vary from $\sim 1 \mathrm{mg} \mathrm{cm}^{-2} \mathrm{yr}^{-1}$ in the Western MED to $\sim 2 \mathrm{mg} \mathrm{cm}^{-2} \mathrm{yr}^{-1}$ in the Eastern MED, and account for 10-20\% of the recent deep-sea sedimentation in the Western MED (3-15 $\left.\mathrm{mg} \mathrm{cm}^{-2} \mathrm{yr}^{-1}\right)$.

Acknowledgements: This work was partially supported by the Commission of the European Communities/Sciences and Technology Environmental Programme Contract STEP-CT N-080-0080, and by World Meteorological Organisation Contract 20.028/A/CNS. This is the Istituto di Geologia Marina-Consiglio Nazionale delle Ricerche scientific contribution $\mathrm{N}^{\circ}$ xxxx. We thank the Italian Meteorological Service, at the Capo Carbonara station, for the use of its site and meteorological data during sampling. We also thank G. Rampazzo and S. Cristini for discussions and trace metals data, G. Cesari for sampling help, G. Quarantotto for chemistry work and G. Zini for drawings. 


\section{REFERENCES}

Bergametti G., P. BAut-MenARD and D. MARtin (1988) Trace metals in the Mediterranean atmosphere. Air Pollution Research Reports, 14, 88-95.

Bergametti G., L. Dutot, P. BuAT-MENARD and E. REMOUdAKI (1989A) Seasonal variability of the elemental composition of atmospheric aerosol particles over the northwestern Mediterranean. Tellus, $41 \mathrm{~B}, 553-561$.

Bergametti G., L. Gomes, E. Remoudaki, M. Desbois, D. Martin and P. BuAt-Menard (1989B) Present-day transport and deposition patterns of African dusts to the North-Western Mediterranean. In: Paleoclimatology and Paleometeorology: Modern and Past Patterns of Global Atmospheric Transport., M. Leinen and M. Sarnthein, editors, Kluwer, Dordrecht, pp. 227-252.

BÜCHER A. J. DUBIEF, and C. LUCAS (1983) Retombees estivales de poussieres sahariennes sur l'Europe. Revue de Geologie Dynamique et de Geographie Physique, 24, 153-165.

BÜCHER A. (1989) Fallout of Saharan dust in the northern Mediterranean region. In: Paleoclimatology and Paleometeorology: Modern and Past Patterns of Global Atmospheric Transport, M. Leinen and M. Sarnthein, editors, Kluwer, Dordrecht, p. 565-584.

CABOI R., CRISTINI A. AND F. FRAU (1995). Metal interactions in rainwater (Sardinia, W Mediterranean Sea). In: Water-Rock Interactions, Kharaka and Chudaev, editors, Balkema, Rotterdam, p. 337-340.

Chester, R., G.G. BAXter, A.K.A. Behairy, K. Connor, D.Cross., H. Elderfield and R.C.PADGHAM (1977) Soil-sized eolian dusts from the lower troposphere of the Eastern Mediterranean Sea. Marine Geology, 24, 201-217.

Chester R., E.J.Sharples, G.S. SANDERS and A.C. SAYdAM (1984) Saharan dust incursion over the Tyrrhenian Sea. Atmospheric Environment, 18, n.5, 929-935.

ChESTER R.,F.J. Lin AND K.J.T. MuRPhY (1989). A three stage sequenatial leaching scheme for the characterization of the sources ad environmental mobility of trace metals in the marine aerosols. Evironmental Technology Letters, 10, 887-900.

Chester R., M. Nimmo, K.J.T. MurPhY and E. NiCHOLAS (1990). Atmospheric trace metals transported to the W Mediterranean: data from a station on Cap Ferrat. Water Pollution Research Reports, 20, 597-612

Chester R., M. Nimmo, M. Alarcon and P. CorCoran (1992) The chemical character of the Western Mediterranean aerosol. Water Pollution Research Reports, 28, 495-504.

Chester R., M. Nimmo, M. Alarcon, C. SAydam, K.J.T. Murphy, G.S. SANDERS and P. Corcoran (1993a) Defining the chemical character of aerosols from the atmosphere of the Mediterranean Sea and surroundings regions. Oceanologica Acta, 16, 231-245.

Chester R., K.J.T. Murphy, F.J. Lin, A.S. Berry, G.A. Bradshaw and P. Corcoran (1993b) Factors controlling the solubilities of trace metals from non-remote aerosols deposited to the sea surface by the "dry" deposition mode. Marine Chemistry, 42, 107-126.

Chester R., M. Nimmo and S. Keyse (1995a) The influence of Saharan and Midddle Eastern desertderived dust on the trace metal composition on the trace metal composition of Mediterranean aerosols and rainwaters: an overview. The impact of African dust across the Mediterranean, Oristano 4-7 October 1995, p. 28 (abs).

Chester R., M. Nimmo, S. Keyse and P. CORCORAN (1995b) Rain-water aerosol trace metal relationships at Cap Ferrat, a coastal site in the Western Mediterranean (in prep.).

Correggiari A., S. Guerzoni, R. LenaZ, G. QuARANTOTTO and G. RAMPAZZO (1989) Dust deposition in the Central Mediterranean (Tyrrhenian and Adriatic Seas): relationship with marine sediments and riverine input. Terra Nova, 1, 549-558.

COUdE-GAussen G. and 6 OTHERs (1987) Saharan dust on Forteventura Island (Canaries): chemical and mineralogical characteristics, air mass trajectories, and probable sources. Journal of Geophysical Research, 92, 9753-9771.

D'AlmeIDA G.A. (1986) A model for Saharan dust transport. Journal of Climate and Applied Meteorology, 25, 903-916.

D'AlmeIDA G.A. and L. SCHÜTZ (1983) Number, mass and volume distribution of mineral aerosol and soils of the Sahara. Journal of Climate and Applied Meteorology, 22, 233-243.

Dayan U., J. Hefter, J. MiLler and G. GutMAN (1991). Dust intrusion into the Mediterranean Basin. Journal of Applied Meteorology, 30, 1185-1199.

DAYAN U., J. HeFTER and J. MiLleR (1995). Seasonal distribution of the planetary boundary layer depths over the Mediterranean basin. The impact of African dust across the Mediterranean, Oristano 4-7 October 1995, p. 11 (abs). 
De Angelis M. and A. Gaudichet (1991) Saharan dust deposition over Mont Blanc (French Alps) during the last 30 years. Tellus, 43B, 61-75.

DESSENS J. and P. VAN DINH (1990) Frequent Saharan dust outbreaks north of the Pyrenees: a sign of climatic change ? Weather, 45, 327-333.

Dulac F., P. BUAT-MENARD, M. ARNOLD and U. EZAT (1987) Atmospheric input of trace metals to the Western Mediterranean Sea: 1: Factors controlling the variability of atmospheric concentrations. Journal of Geophysical Research, 92, 8437-8453.

Dulac F., P. Buat-Menard, U. EzAT, S. MelKi and G. BergametTi (1989) Atmospheric input of trace metals to the Western Mediterranean Sea: uncertainities in modelling dry deposition from cascade impactor data. Tellus, 41B, 362-378.

Dulac F., D. Tanre', G. Bergametti, P. Buat-Menard, M. Desbois and D. Sutton (1992) Assessment of the frican airborne dust mass over the Western Mediterranean using meteosat data. Journal of Geophysical Research, 97, 2489-2506.

DULAC F. (1995). A review of quantitative remote sensing studies of African dust transport to the Mediterranean. The impact of African dust across the Mediterranean, Oristano 4-7 October 1995, p. 5 (abs).

EMELYANOV E. (THIS VOLUME) Sediment type and distribution in the Mediterranean, part I.

ERIKSSON K.G. (1979) Saharan dust sedimentation in the Western Mediterranean Sea. In: Saharan dust: mobilization, transport deposition, C. MORALES, editors, Wiley, pp. 197-210.

FranZEN L.G., M. HJIELMROOS, P. KÅllBERG, E. BRORSTRÖM-LUNDEN, S. JUNTTO and A. SAVOLAINEN (1994) The 'Yellow snow' episode on Northern Fennoscandia, March 1991: a case study of longdistance transport of soil, pollen and stable organic compounds. Atmospheric Environment, 28, n.22, 3587-3604.

GANOR E. and Y. MAMANE (1982) Transport of Saharan dust across the Eastern Mediterranean. Atmoapheric Environment, 16, n. 3, 581-587.

GILMAN C. and C. GARRETT (1994) Heat flux parametrisazion for the Mediterranean Sea: the role of atmospheric aerosols and constraints from the water budget. Journal of Geophysical Research, 99, 51519-5134.

Glavas S. (1988) A wet-only precipitation study in a Mediterranean site, Patras, Greece. Atmospheric Environment, 22, 1505-1507.

Guerzoni S., G. Rovatti, E. Molinaroli and G. Rampazzo (1987) Total and "selective" extraction methods for trace metals in marine sediment reference samples (Mess-1, NBS 1646). Chemistry in Ecology, 3, 39-48.

Guerzoni S., W. Landuzzi, R. Lenaz, G. Quarantotto, G. Cesari, R. Rampazzo and E. MolinAROLI (1992a) Mineral atmospheric particulate from South to NW Mediterranean: seasonal variations and characteristics. Water Pollution Reaserch Reports, 28, 483- 493.

Guerzoni S., Cesari G., LenAZ R. and L. CRUCIANI (1992b). A new sampling station at the coastal site of Capo Carbonara (Sardinia, Central Mediterranean): preliminar data and technical proposal. UNEP/MAP Technical Report Series, 64, 33-40

Guerzoni S., W. LANDuZZI, R. LEnAZ, G. QuARANTOtTo, G. RAMPAZZO, E. Molinaroli, C. TuRETTA, F. VISIN, G. CESARI and S. CRISTINI (1993) Fluxes of soluble and insoluble metals and nutrients from the atmosphere to the Central Mediterranean Sea. Water Pollution Reaserch Reports, 30, 438-493.

Guerzoni S., G. Quarantotto, E. Molinaroli and G. Rampazzo (1995a) More data on source signature and seasonal fluxes to the Central Mediterranean Sea of aerosol dust originated in desert areas. Water Pollution Research Reports, 32, 267-273.

Guerzoni S., A. Cristini, R. CABOI, O. Le Bolloch, I. Marras and L. Rundeddu (1995b) Ionic composition of rainwater and atmospheric aerosols in Sardinia, Southern Mediterranean. Water Air and Soil Pollution, 85 (4), 2077-2082.

GuIEU C. (1991) Apports atmospheriques a la Mediterraneaniterranee nord-occidentale. These de doctorat de l' Université de Paris: 255 pp.

GUIEU ET AL (THIS VOLUME) Atmospheric input of dissolved and particulate metals in the NW Mediterranean.

HARDY R. and M. TUCKER (1988) X-ray powder diffraction of sediments. In: Techniques in Sedimentology, Oxford, Blackwell Scientific Publication, pp. 394.

HARRIS J.M. (1982). The GMCC atmospheric trajectory program. In : NOAA Technical memorandum ERL ARL-116, NGAA, Boulder, Colorado, 32 pp.

KuBILAY N:; S. YEMENICIOGLU and C. SAYDAM (1994) Trace metal charcterisation of airborne particles from the Northeastern Mediterraneaniterranea. Fresenius Environmental Bullettin, 8, 444-448. 
Lambert C., C. Moulin, F. Guillard, P. Chazette, W. Guelle, J. Poitou and F. Dulac (1995). Tenyears (1983-1992) monitoring of Saharan dust concentrations over the Mediterranean Sea using Meteosat data. The impact of African dust across the Mediterranean, Oristano 4-7 October 1995, p. 20 (abs).

LE BOLlOCH O. and S. GUERZONI (1995). Acid and alkaline deposition in precipitation on the Western coast of Sardinia, Central Mediterranean $\left(40^{\circ} \mathrm{N}, 8^{\circ} \mathrm{E}\right)$. Water Air and Soil Pollution, 85 (4), $2155-$ 2160.

LITTMANN T., J. STEINRÜCKE and F. GASSE (1990) African mineral aerosol deposition in West Germany 1987-89: characteristics, origin and transport mechanisms. Geoökodynamik, 11, 163-189.

LOŸE-PILOT M.D., J.M. MARTIN and J. MORELLI (1986) Influence of Saharan dust on the rain acidity and atmospheric input to the Mediterranean. Nature, 321, 427-428.

LOŸE -PILOT M.D., J.M. MARTIN and J. MORELLI (1989) Atmospheric input of particulate matter and inorganic nitrogen to the north-western Mediterranean. Water Pollution Reaserch Reports, 13, 368376.

LOŸE -PILOT M.D. and J.M. MARTIN (1995). Saharan dust input in Corsica: an 11 years record. The impact of African dust across the Mediterranean, Oristano 4-7 October 1995, p. 38 (abs).

MazzuCotelli A., V. LANDUZzi, R. LenAZ, F.OliVeri, L. TOMAdin and R. VANnuCCI (1984). Polveri in sospensione nella bassa atmosfera del Mare Tirreno e del Canale di Sicilia (crociera Ban 80). Memorie Società Geologica Italiana, 27, 311-321.

Molinaroli E., S. Guerzoni and G. RAMPAZzo (1993) Contribution of Saharan dust to the Central Mediterranean basin. Geological Society of America, SP 284, 303-312.

MolinAROLI E. and IBBA G (IN PRESS) Occurrence of palygorskite in aerosol dust (dry \& wet) of desert source in SE Sardinia, W Mediterranean. Giornale di Geologia e Geologia Marina,.

Mongardi S., L. CAPOTONDI, A. CORREgGIARI and F. TRINCARDi (1994) Basin-wide mass transport during the late-Quaternary sea level rise, Paolo slope basin. IAS 15th Regional Meeting, 13-15 April 1994, Ischia, Italy (abs).

MurPhy K.J.T. (1985). Trace metal chemistry of the Atlantic aerosol. PhD Thesis, University of Liverpool, UK.

Nihlen T. AND J.O. MATTSSON (1989). Studies on eolian dust in Greece. Geografiska Annaler, 71, 269274.

Prodi F. and G. FEA (1979) A case of transport and deposition of Saharan dust over the Italian Peninsula and southern Europe. Journal of Geophysical Research, 84C, 6951-6960.

ProsPERo J.M. (1981) Arid regions as sources of mineral aerosols in the marine atmosphere. Geological Society of America, SP 186, 71-85.

PYE K. (1992). Aeolian dust transport and deposition over Crete and adjacent parts of the Mediterraean Sea. Earth Surface Processes and Landforms, 17, 271-288.

RAHN K.A. (1976) The chemical composition of the atmospheric aerosol. Tech. Rep., Graduate School of Oceanography, University of Rhode Island, Kingston, R.I.

REA D.K. (1994) The paleoclimatic record provided by eolian deposition in the deep sea: the geologic history of wind. Reviews of Geophysics, 32,2, 159-195.

REIFF J., Forbes G.S., SPIEKSMA F.T.M. and J.J. REYNDERS (1986) African dust reaching northwestern Europe: a case study to verify trayectory calculations. Journal of Climate and Applied Meteorology, 25, 1543-1567.

REMOUDAKI E., G. BERGAMETTI and R. LOSNO (1991). On the dynamic of the atmospheric input of $\mathrm{Cu}$ and $\mathrm{Mn}$ into the Western Mediterranean Sea. Atmospheric Environment, 25A, 733-744.

Robert C. et A.GAUTHIER (1989) Origine saharienne des argiles des lacs d'alitude en Corse (France): une conséquence dela dynamique des anticyclones mobiles polaires. C.R. Acad. Asci. Paris, II, $1025-1030$.

Roda F., J. Bellot, A. Avila, A. Escarre', J. PinOl And J. Terradas (1993). Saharan dust and the atmospheric inputs of elements and alkalinity to Mediterranean ecosystems. Water, Air and Soil Pollution, 66, 277-288.

SCHÜTZ L. (1989). Atmospheric mineral dust - properties and source markers. In: Paleoclimatology and Paleometeorology: Modern and Past Patterns of Global Atmospheric Transport., M. Leinen and M. Sarnthein, editors, Kluwer, Dordrecht, pp. 359-383.

SLINN S.A. AND W.G.N. SLINN (1980). Prediction for particle deposition on natural waters. Atmospheric Environment, 14, 1013-1016.

STANLEY D.J., ReHAUlt J.P. and R. STUCKENRATH (1980). Turbid-layer bypassing model: the Corsican trough, Northwestern Mediterranean. Marine Geology, 37, 19-40. 
TAYLOR S.R. (1964) Aboundance of chemical elements in the continental crust: a new table.Geochimica and Cosmochimica Acta, 28, 1237-1285.

TOMADIN L. (1981) Provenance and dispersal of clay minerals in recent sediments of the Central Mediterranean Sea. In: Sedimentary basins of Mediterranean margins, ed. F.C. Wezel, 313-324.

TOMADIN L. and M. BORGHINI (1987) Source and dispersal of clay minerals from present and Late Quaternary sediments of Southern Adriatic Sea. The 6th Meeting of the European Clay Groups, (Spain), 537-538.

TOMADIN L., R. LENAZ, W. LANDUZZI, A. MAZZUCOTELLI, and R. VANNUCCI (1984) Wind-blown dusts over the Central Mediterranean. Oceanologica Acta, 7, 1, 13-23.

TOMADIN L., R. LENAZ (1989) Eolian dust over the Mediterranean and their contribution to the present sedimentation. In: Paleoclimatology and Paleometeorology: Modern and Past Patterns of Global Atmospheric Transport., M. Leinen and M. Sarnthein, editors, Kluwer, Dordrecht, pp. 267-282.

TSCHIERsCH J., B. Hietel, P. SCHRAMEL and F. TrAutner (1990) Saharan dust at Jungfraujoch. Journal of Aerosol Sciences, 21, suppl.1, S357-S360.

VENKATARATHNAM K. and W.B.F. RYAN (1971) Dispersal patterns of clay minerals in the sediments of the Eastern Mediterranean Sea. Marine Geology., 11, 261-282.

WAGENBACH D. and K. GEIS (1989) The mineral dust record in a altitude alpine glacier (Colle Gnifetti, Swiss Alps). In: Paleoclimatology and Paleometeorology: Modern and Past Patterns of Global Atmospheric Transport., M. Leinen and M. Sarnthein, editors, Kluwer, Dordrecht, pp. 543-564.

ZuO E. (THIS VOLUME) Sedimentation rates in the Western Mediterranean, part II. 


\section{$\underline{\text { APPENDIX }}$}

\section{$\underline{\text { Aerosols }}$}

All aerosol samples were collected with a high volume $\left(60 \mathrm{~m}^{3} / \mathrm{h}\right)$ Sierra Andersen $\odot$ sampler, using filters made of polyester (PE) monofilament fabric (Estal Mono, SSTahl@), with a Whatman ${ }^{\circledR} 41$ (W41) backup. The filters are 841", with a mesh opening of $10 \mu \mathrm{m}$ and thread diameter of $40 \mu \mathrm{m}$. The efficiency of PE filters was calibrated against both W41 and Teflon "total" filters $(0.22 \mu \mathrm{m}$ poresize $)$ was an 80 and $95 \%$, respectively. The sampling time ranged from 48 to 72 hours. Filter blanks were run every 10 aerosol samples and checked chemically. The filters are washed in acidified DDW, dried overnight and weighted before sampling. After collection, the filters were left overnight in the same drybox and re-weighted (to get the Total Suspended Particulate value $=$ TSP). This insures that all samples are brought to the same degree of dryness, thus avoiding weighting errors. Then the exposed Hi-Vol filters were sonnicated in a Milli-Q DD water bath for 20-30 minutes to dissolve salts and to resuspend the insoluble particles from filter. After that, subsamples for mineralogical, chemical, and grain size analyses were taken, and the rest of the solution was filtered (on pre-weighted $0.22 \mu \mathrm{m}$ diameter Nuclepore ${ }^{\odot}$ polycarbonate filters). The particles on the filter were dried in a dry-box and re-weighted (to obtain the Mineral Suspended Particulate value $=$ MSP in $\mu \mathrm{g} / \mathrm{m}^{3}$ ). To check the efficiency of resuspension procedure the original filters were reweighted at the end, and the difference in weight between the original empty filter and after the procedure resulted to be less than $1 \%$ of the insoluble material. Considerable care was taken to minimize contamination, both in the laboratory and in the field. All sample manipulation in the laboratory occurred in a class 100 clean room. W41 and Nuclepore filters, as received from the manufacturer, are extremely clean with respect to the chemical species of interest in this study. Consequentely it was not necessary to preclean the filters prior to sampling.Polyester filters, on the contrary, were acid washed and rinsed several time with Milli-Q water. Filter chemical blanks were determined from filters that were taken into the field and handled in the same manner as those used for sample collection.

\section{$\underline{\text { Rain }}$}

Rain samples were collected using a Wet \& Dry (ARS 200 MTX ${ }^{\circledR}$ ) automatic collector, and the sample is filtered through a $0.22 \mu \mathrm{m}$ diameter Nuclepore ${ }^{\bigcirc}$ polycarbonate preweighted filter within few hours, and subdivided into two phase fractions, soluble and insoluble. The insoluble fraction was dried in a dry-box and reweighted (to obtain the total particulate concentration value $=$ TPC in $\mathrm{mg} / \mathrm{l})$.Blanks were run periodically, by making all operations with only Milli-Q water instead of samples. Filtering was done with a Millipore ${ }^{\odot}$ Sterifil unit, equipped with a pre-filter on the cover, to avoid contamination with ambient air.

\section{Chemical analyses}

Particulates in precipitation were analyzed in the same way as the insoluble fraction of the aerosols collected with the Hi-Vol sampler. Following dissolution in $\mathrm{HNO}_{3}+\mathrm{HF}$ in teflon bombs, the major elements ( $\mathrm{Fe}, \mathrm{Si}, \mathrm{Al}, \mathrm{Ca}, \mathrm{Mg}$ ) were analyzed on a flame atomic absorption spectrophotometer, and trace elements $(\mathrm{Cd}, \mathrm{Pb}, \mathrm{Cr}, \mathrm{Zn})$ were analyzed using a graphite furnace. Analytical procedures are presented in detail elsewhere (Guerzoni et al., 1987, 1992) and analytical errors were lower than $5 \%$ for $\mathrm{Al}, \mathrm{Ca}, \mathrm{Fe}, \mathrm{Mg}, \mathrm{Si}$, between 5 and $10 \%$ for $\mathrm{Cr}, \mathrm{Pb}, \mathrm{Zn}$ and $12 \%$ for $\mathrm{Cd}$.

\section{Grain-size and mineralogical analyses}

The volume size distribution of the insoluble fraction in aerosols (100 samples) and in rain waters (2 Saharan dust outbreaks: on March 1992 and October 1993) was carried out by the Coulter Counter Technique (Model TA II Coulter Counter). Orifice tubings of 50 and $280 \mu \mathrm{m}$ were used to investigate the size domain after a preliminary scansion during which no longer particles were detected. High resolution size distributions were achieved preforming triplicate analytical runs and connecting the Coulter to an automatic data acquisition system of an Apple II microcomputer and a multiplexing unit based on IC CMOS 4051, controlled by a Versatile Interface Adapter (VIA6522) card (Boldrin et al., 1986).

Mineralogical studies were performed on 55 aerosols separated in two fractions $(0.2-102 \mu \mathrm{m}$, and $<4 \mu \mathrm{m})$ by X-ray diffraction (Philips PW 1730 instrumen). The first fraction $(0.2-102 \mu \mathrm{m})$ was utilized for the determination of the bulk mineralogy. The Stokes settling velocity was applied for size fractionation. Identification of minerals and determination of their abundance (fraction $<4 \mu \mathrm{m}$ ) were 
based on the procedure of Biscaye (1965). A semiquantitative technique was used, and the weighted percentages of the different clay minerals were calculated from peak areas.

Aerosols and rain waters were filtered on $0.22 \mu \mathrm{m}$ diameter Nuclepore ${ }^{\complement}$ polycarbonate filters. Subsequently the samples were mounted on scanning electron microscopy (SEM) stubs, and coated with $20 \AA$ layer of AU prior to observation with the SEM (Cambridge Stereoscan 250 MK3) and chemical analysis by an attached X-ray energy dispersive system (EDS).

\section{$\underline{\text { Flux calculations }}$}

Fluxes were calculated for both rainfall and insoluble fraction of the aerosol. For precipitation samples the particulate "wet" flux $\left(\mu \mathrm{g} / \mathrm{cm}^{2}\right)$ was calculated by multiplying the TPC concentration (in $\mathrm{mg} / \mathrm{l})$ by the amount of rain (liters) and dividing by the area of the sampler $\left(660 \mathrm{~cm}^{2}\right)$. For the aerosols, the "dry" flux $(\mathrm{Fx})\left(\mu \mathrm{g} / \mathrm{cm}^{2}\right)$ was calculated according to the following equation: $\mathrm{Fx}=\mathrm{c} * \mathrm{~V}_{\mathrm{d}} * \mathrm{t}$, where $\underline{\mathrm{C}}$ is the MSP value in $\mu \mathrm{g} / \mathrm{m}^{3}, \underline{\mathrm{V}}$ is the deposition velocity in $\mathrm{cm} / \mathrm{sec}$, and $\mathrm{t}$ is the sampling duration in seconds. The deposition velocity used here $(2.5 \mathrm{~cm} / \mathrm{sec})$ was choosen within the range of literature values, for aerosols largely dominated by mineral particles with a median grain-size of 2-10 $\mu \mathrm{m}$ (Dulac et al., 1989; Slinn and Slinn, 1980).

\section{Enrichment factor (EF)}

The degree to which a trace metal in a particulate aerosol is enriched, or depleted, relative to specific source can be assessed to a first approximation using an enrichment factor (EF). For crustal sources, Al, is normally used as the source indicator element and the Earth's crust as the source material (Taylor, 1964). The $\mathrm{EF}_{\text {crust }}$ value is then calculated according to an equation of the type:

$$
E F_{\text {crust }}=\left(C_{x p} / C_{A l p}\right) /\left(C_{x c} / C_{A l c}\right)
$$

where $\left(C_{x p}\right.$ and $\left.C_{A l p}\right)$ are the concentrations of a trace metal $\underline{x}$ and $\underline{A l}$, respectively, in the aerosol, and $\left(C_{X c}\right.$ and $\underline{\left.\mathrm{C}_{\mathrm{Alc}}\right)}$ are their concentrations in average crustal material. By convention, an arbitrary average $\mathrm{EF}_{\text {crust }}$ value of $<10$ is taken as an indication that an element in an aerosol has a significant crustal source, and these are termed non-enriched elements (NEEs). In contrast, an $\mathrm{EF}_{\text {crust }}$ value of $>10$ is considered to indicate that a significant proportion of an element has a non-crustal source, and these are termed the anomalously enriched elements (AEEs). Some trace metals (e.g. Al, Fe,) in aerosols are always crust-controlled. In contrast, other trace metals can change their character as material from different sources is mixed together in the atmosphere: e.g. metals such as $\mathrm{Cu}, \mathrm{Zn}$ and $\mathrm{Pb}$, which behave as AEEs in some aerosols, can have their $\mathrm{EF}_{\text {crust }}$ values reduced to $<10$, i.e. they behave as NEEs, as the proportions of crustal material in an aerosol increases. 


\section{FIGURE CAPTIONS}

Fig. 1 Locations of the collection sites for particulate aerosol samples (full dots, $\boldsymbol{a}$ to $\boldsymbol{f}$ ) and deposition measurements (triangles) in and around the MED Sea . Shaded areas (1 to 4) represent the most productive sources of Saharan dust (from D'Almeida, 1986). Arrows indicate the main routes of dust outbreaks toward Mediterranean and continental Europe (see text for explanations). Full bars indicate areas where recent and Holocene bulk sedimentation rates are available $\left(\mathbf{A}=\right.$ Rhone area, $40-42^{\circ} \mathrm{N} ; \mathbf{B}=$ Tyrrhenian Sea, $\left.39-41^{\circ} \mathrm{N}\right)$.

Fig. 2 Plot of Mineral Suspended Particulates (MSP) values in air (left axis, $\mu \mathrm{g} \mathrm{m}^{-3}$ ) and total particulate content (TPC) in precipitation events (right axis, mg 1-1) over the twelve months period (Oct '90-Apr '91 and May-Sept '92). The rain events with TPC values $<0.1 \mathrm{mg} \mathrm{1^{-1 }}$ are not indicated in the figure. The inset shows the two-weeks period described in detail in the text and listed in Table 2.

Fig. 3 Monthly averages of dry and wet fluxes of Saharan particulates. Dry monthly data are the sum of at least ten 3-days dust samples, and were calculated for the period October 1990-April 1991, and May-October 1992. The two curves represent: $\mathbf{A}=$ the dust fallout in Europe (from Bücher, 1989), $\mathbf{B}=$ the frequency of northward transport of dust from Africa (from D' Almeida, 1986). Filled bars represent monthly precipitation at Sardinia.

Fig. 4 Volume size distribution of Saharan dust, dry mode, reaching Sardinia, (A) broken line: October 1990; solid line: March 1991. Volume size distribution of Saharan dust, wet mode, reaching Sardinia, (B) broken line: March 1992; solid line: October 1993.

Fig. 5 Comparison of diffraction patterns of bulk mineralogy in dry Saharan outbreaks (sample 2 and 42): $\mathrm{Ch}=$ chlorite, $\mathrm{D}=$ dolomite, $\mathrm{K}=\mathrm{kaolinite}, \mathrm{KF}=\mathrm{k}$-feldspars, $\mathrm{I}=$ Illite, $\mathrm{P}=$ plagioclase, $\mathrm{Pa}=$ palygorskite, $\mathrm{Q}=$ quartz. Percentages of clay minerals in $<4 \mu \mathrm{m}$ fraction of five Saharan events (bar chart) it is also shown.

Fig. 6 Clay mineral compositions from some eolian dusts (dry) and sediments from the MED Basin. 1= Sardinia, Saharan dusts, present study; $\mathbf{2}=$ Tyrrhenian dusts M5-M8, Chester et al., 1984; 3= BAN 80 dusts, Mazzucotelli et al., 1984; 4= Eastern MED dusts, Chester et al., 1977; 5= Tyrrhenian dusts M2, M3, M4, and M9, Chester et al., 1984; 6= EOLO81-1 and EOLO 81-2 cruises, Tomadin et al., $1984 ; \mathbf{7}=$ Sardinia, non-Saharan dusts, present study; 8= Northern Tyrrhenian deep-sea sediments, Tomadin, 1981; 9= Southern Tyrrhenian deepsea sediments, Tomadin, 1981; 10 $=$ Northern Adriatic deep-sea sediments, Tomadin e Borghini 1987; 11= Southern Adriatic deep-sea sediments, Tomadin e Borghini, 1987; and 12= average of thirty Eastern MED deep-sea sediments, Venkatarathnan and Ryan, 1971. 


\begin{tabular}{lllllllll}
\hline type of event & AM & $\begin{array}{l}\text { MSP } \\
\text { GM }\end{array}$ & R & No. & AM & GM & R & No. \\
\hline $\begin{array}{lllllllll}\text { background } \\
\text { Saharan }\end{array}$ & 2.8 & 2.4 & $0.5-5$ & 60 & 1.8 & 0.7 & $0.01-4$ & 15 \\
enriched & 6.9 & 6.8 & $2-10$ & 30 & 8.6 & 8.5 & $7-12$ & 5 \\
"pure" & 15.9 & 15.0 & $8-24$ & 8 & 22.2 & 18.3 & $6-55$ & 9 \\
"outbreaks" & 44 & 43.9 & $40-47$ & 2 & 323 & 263 & $135-512$ & 2 \\
\hline
\end{tabular}

Tab. 1 - Concentration of insoluble particulates in air and rain $\mathrm{MSP}=$ mineral suspended particulate in aerosols $\left(\mathrm{g} \mathrm{m}^{-3}\right)$ $\mathrm{TPC}=$ total particulate content in rain $\left(\mathrm{mg} \mathrm{l}^{-1}\right)$

$\mathrm{AM}=$ arithmetic mean; $\mathrm{GM}=$ geometric mean; $\mathrm{R}=$ range; $\mathrm{No}=$ number of samples background : $\quad \mathrm{Al} / \mathrm{Si}<0.3 ; \mathrm{Ca}<2 \%$; associated rain $\mathrm{pH}<5.60 ; \mathrm{Ca}<200 \mu \mathrm{Eq} / 1$ Saharan: crust encriched $=\mathrm{Al} / \mathrm{Si}>0.3 ; \mathrm{Ca}>2 \%$;

"pure" and "outbreaks" = $\mathrm{Al}>1000 \mathrm{ng} \mathrm{m}^{-3} ; \mathrm{Al} / \mathrm{Si}>0.4 ; \mathrm{Ca}>4 \%$

\begin{tabular}{|c|c|c|c|c|c|}
\hline$\overline{\text { date }}$ & $\begin{array}{l}\text { wet/ } \\
\text { dry }\end{array}$ & $\begin{array}{l}\mathrm{MSP} \\
\mu \mathrm{g} \mathrm{m} \mathrm{m}^{-3}\end{array}$ & $\begin{array}{l}\text { flux dry } \\
\mu \mathrm{g} \mathrm{cm}-2\end{array}$ & $\mathrm{pH}$ & $\begin{array}{l}\text { flux wet } \\
\mu \mathrm{g} \mathrm{cm}-2\end{array}$ \\
\hline $\begin{array}{l}5 \text { Oct } \\
5-8 \text { Oct }\end{array}$ & $\begin{array}{l}\text { w } \\
d\end{array}$ & 2.4 & 1.6 & 5.29 & 0.3 \\
\hline $8 \mathrm{Oct}$ & w & & & 6.45 & 5.6 \\
\hline 90ct & w & & & 6.87 & 14.7 \\
\hline 8-11 Oct & d & 24.0 & 15.6 & & \\
\hline \multicolumn{2}{|c|}{ Total flux (5-11 Oct) } & & 17.2 & & 20.6 \\
\hline 11-14 Oct & $d$ & 40.0 & 26.0 & & \\
\hline 16 Oct & w & & & 6.97 & 8.2 \\
\hline 14-17 Oct & d & 23.7 & 15.4 & & \\
\hline 19 Oct & w & & & 6.33 & 8.8 \\
\hline $17-20$ Oct & d & 5.4 & 3.5 & & \\
\hline \multicolumn{2}{|c|}{ Total flux (11-20 Oct) } & & 44.9 & & 17.0 \\
\hline
\end{tabular}

Tab. 2 - MSP values and deposition fluxes (dry and wet) of particles during two continuous periods (5-11/11-20 October 1990). (for flux calculations- see Appendix; see also inset of Fig. 2). 


\begin{tabular}{lll}
\hline $\begin{array}{l}\text { Trace } \\
\text { Metal }\end{array}$ & \multicolumn{2}{c}{$\begin{array}{c}\text { Atlantic north east } \\
\text { trades }\end{array}$} \\
\hline & Conc. & EF $_{\text {crust }}$ \\
\hline $\mathbf{A l}$ & 5925 & 1.0 \\
$\mathbf{F e}$ & 3865 & 1.0 \\
$\mathbf{C r}$ & 10 & 1.4 \\
$\mathbf{Z n}$ & 16 & 3.2 \\
$\mathbf{P b}$ & 6.9 & 7.7 \\
$\mathbf{C d}$ & 0.12 & 8.3 \\
\hline
\end{tabular}

Table 3 - Average trace metal concentrations and $E F_{\text {crust }}$ values for Saharan aerosols from the Atlantic north east trades, Reference, Murphy (1985); average of 6 samples. 


\begin{tabular}{|c|c|c|c|c|c|c|c|c|c|c|c|c|}
\hline \multirow{2}{*}{$\begin{array}{l}\text { Trace } \\
\text { metal }\end{array}$} & \multicolumn{2}{|c|}{ Blanes $^{\mathbf{a}}$} & \multicolumn{2}{|c|}{ Tour du Valat ${ }^{b}$} & \multicolumn{2}{|c|}{ Cap Ferrat $^{c}$} & \multicolumn{2}{|c|}{ Corsicad $^{d}$} & \multicolumn{2}{|c|}{ Erdemlie $^{e}$} & \multicolumn{2}{|c|}{ Sardinia $^{f}$} \\
\hline & Conc. & $\mathbf{E F}_{\text {crust }}$ & Conc. & EF $_{\text {crust }}$ & Conc. & $\mathbf{E F}_{\text {crust }}$ & Conc. & $E_{\text {crust }}$ & Conc. & $\mathbf{E F}_{\text {crust }}$ & Conc. & $\mathbf{E F}_{\text {crust }}$ \\
\hline Al & 38 & 1.0 & 380 & 1.0 & 370 & 1.0 & 168 & 1.0 & 680 & 1.0 & 164 & 1.0 \\
\hline $\mathbf{F e}$ & 316 & 1.3 & 275 & 1.1 & 320 & 1.3 & 144 & 1.3 & 685 & 1.5 & 85 & 0.76 \\
\hline $\mathrm{Cr}$ & 1.8 & 3.4 & - & - & 2.5 & 5.6 & - & - & 10.8 & 13 & 1.6 & 8.1 \\
\hline Zn & 50 & 151 & 60 & 186 & 41 & 130 & 19 & 134 & 19 & 33 & 3.4 & 24 \\
\hline $\mathbf{P b}$ & 50 & 843 & 56 & 982 & 58 & 1045 & 16 & 635 & 30 & 294 & 9.8 & 398 \\
\hline Cd & 0.60 & 628 & 0.51 & 559 & 0.36 & 405 & - & - & 0.19 & 116 & 0.03 & 76 \\
\hline
\end{tabular}

Table 4 - Geometric average trace metal concentrations EF crust values for particulate aerosols from a number of sites (refer to Fig. 1 for locations) in the Western and Central Mediterranean sites. (conc. units - $\mathrm{ng}^{\mathbf{3}} \mathbf{3}$ of air; for comparability EF crust values have been calculated from the average concentration data).

a. Chester et al. (1992); February, 1989-June, 1989

b. Guieu (1991).

c. Chester et al. (1990); September, 1988-July, 1989.

d. Bergametti et al. (1989); April, 1985-April, 1986.

e. Kubilay et al. (1994); August, 1991-December, 1992.

f.Present paper; October, 1990-April, 1991. 


\begin{tabular}{|c|c|c|c|c|}
\hline \multirow[t]{2}{*}{$\begin{array}{l}\text { Trace } \\
\text { Metal }\end{array}$} & \multicolumn{2}{|c|}{$\begin{array}{l}\text { Aerosol populations with Al concentrations } \\
10^{3} \mathrm{ng} \mathrm{m}^{-3} \text { of air } \\
\qquad \mathrm{n}=7\end{array}$} & \multicolumn{2}{|c|}{$\begin{array}{l}\text { Total aerosol population for the whole } \\
\text { collection period } \\
\qquad \mathrm{n}=55 \\
\end{array}$} \\
\hline & Average conc. & Average $\mathbf{E F}_{\text {crust }}$ & \begin{tabular}{|l} 
Average conc. \\
\end{tabular} & Average $\mathbf{E F}_{\text {crust }}$ \\
\hline$\overline{A l}$ & 2950 & 1.0 & 164 & 1.0 \\
\hline $\mathbf{F e}$ & 1141 & 0.66 & 85 & 0.76 \\
\hline $\mathrm{Cr}$ & 4.4 & 1.4 & 1.6 & 8.1 \\
\hline $\mathbf{Z n}$ & 23 & 13 & 3.4 & 24 \\
\hline $\mathbf{P b}$ & 27 & 79 & 9.8 & 398 \\
\hline Cd & 0.03 & 6.9 & 0.03 & 76 \\
\hline
\end{tabular}

Table 5 - The effect of Saharan dust inputs on trace metal concentrations and EF crust values of aerosols at the Sardinia site (conc. units; $\mathrm{ng} \mathrm{m}^{-3}$ of air).

\begin{tabular}{|c|c|c|c|c|c|c|}
\hline \multicolumn{7}{|c|}{ Cap Ferrat } \\
\hline \multicolumn{7}{|c|}{ Aerosol type scavenged } \\
\hline \multicolumn{4}{|c|}{$\begin{array}{c}\text { European 'background'; } \\
\text { sample 1, pH 3.95 }\end{array}$} & \multicolumn{3}{|c|}{$\begin{array}{c}\text { Saharan dust; } \\
\text { sample 12, pH 6.55 }\end{array}$} \\
\hline $\begin{array}{l}\text { Trace } \\
\text { Metal }\end{array}$ & Conc. & $\mathbf{E F}_{\text {crust }}$ & $\begin{array}{c}\text { \%age total } \\
\text { concentration in } \\
\text { dissolved phase }\end{array}$ & Conc. & $\mathbf{E F}_{\text {crust }}$ & $\begin{array}{c}\text { \%age total } \\
\text { concentration in } \\
\text { dissolved phase }\end{array}$ \\
\hline Al & 140 & 1.0 & 135 & 1462 & 1.0 & 1.15 \\
\hline Co & 0.078 & 1.9 & 67 & 0.58 & 1.3 & 0.50 \\
\hline $\mathbf{N i}$ & 1.88 & 15 & 69 & 2.26 & 1.7 & 23 \\
\hline $\mathrm{Cu}$ & 5.79 & 59 & 86 & 4.0 & 3.9 & 30 \\
\hline $\mathbf{Z n}$ & - & - & - & - & - & - \\
\hline $\mathbf{P b}$ & 26.2 & 1248 & 90 & 3.46 & 16 & 5.2 \\
\hline
\end{tabular}

Table 6 - Total trace metal

concentrations and $E_{\text {crust }}$ values in rain waters that have scavenged

European "background"'and

Saharan dust aerosols; (conc.

units; $\mu \mathrm{g} l^{-1}$, from Chester et al.,

$1995 b)$

\begin{tabular}{llll}
\hline site & flux & \%dry & period \\
& & $\mathrm{g} \mathrm{m}^{-2}$ & \\
& & & \\
\hline Crete1 & $20(6-46)$ & & $1988-90$ \\
Sardinia2 (south) & $5-13$ & 30 & $1990-93$ \\
$\quad 3$ (west) & $2-5$ & 25 & $1992-94$ \\
Corsica4 (inland) & $16(9-25)$ & 15 & $1984-88$ \\
$\quad 5$ (coastal) & 12 & 35 & $1987-89$ \\
Alps6 (Mt.Blanc) & 1 & icecore & $1955-1982$ \\
$" 7$ (Colle Gnifetti) & 0.4 & icecore & $1935-1982$
\end{tabular}

Tab. 7 Saharan dust deposition in various sites (mean annual fluxes), with \% of the dry depositon over the total (Refer to Fig.1 for site locations=triangles).

(1) Nihlen and Mattsson, 1989; Pye, 1992; (2) Guerzoni et al., 1995b; (3) Le Bolloch \& Guerzoni, 1995; (4) Loÿe-Pilot et al., 1989; (5) Bergametti et al., 1989; (6) De Angelis \& Gaudichet et al., 1991; (7) Wagenbach \& Geis, 1989. 


\begin{tabular}{|c|c|}
\hline Subarea & $\begin{array}{l}\text { sedimentation rate } \\
\mathrm{mg} \mathrm{cm}^{-2} \mathrm{yr}^{-1} \quad \mathrm{~mm} \mathrm{yr}^{-1}\end{array}$ \\
\hline$\overline{\text { W.MED Rhone area }(40-429) \wedge \%}$ & $0.04-0.12$ \\
\hline Central MED Tyrrhenian (39-419N) \#\&§ & $\begin{array}{ll}5-15 & 0.07-0.20 \\
\text { dust loading }\end{array}$ \\
\hline $\begin{array}{l}\text { whole ocean@ } \\
\text { present work }\end{array}$ & $\begin{array}{l}0.20-0.25 \\
1(0.2-2.5)\end{array}$ \\
\hline
\end{tabular}

Tab. 8 Bulk sedimentation rates in the Western/Central Mediterranea and average annual dust loadings. (Refer to Fig.1 for site locations=A: W. Med, Rhone area; $\underline{B}:$ Tyrrhenian Sea).

(^) Zuo (this issue); (\%) Loÿe-Pilot et a., 1986; (\#) Mongardi et al.,1994; (§) Stanley et al., 1980, (@) Rea, 1994. 


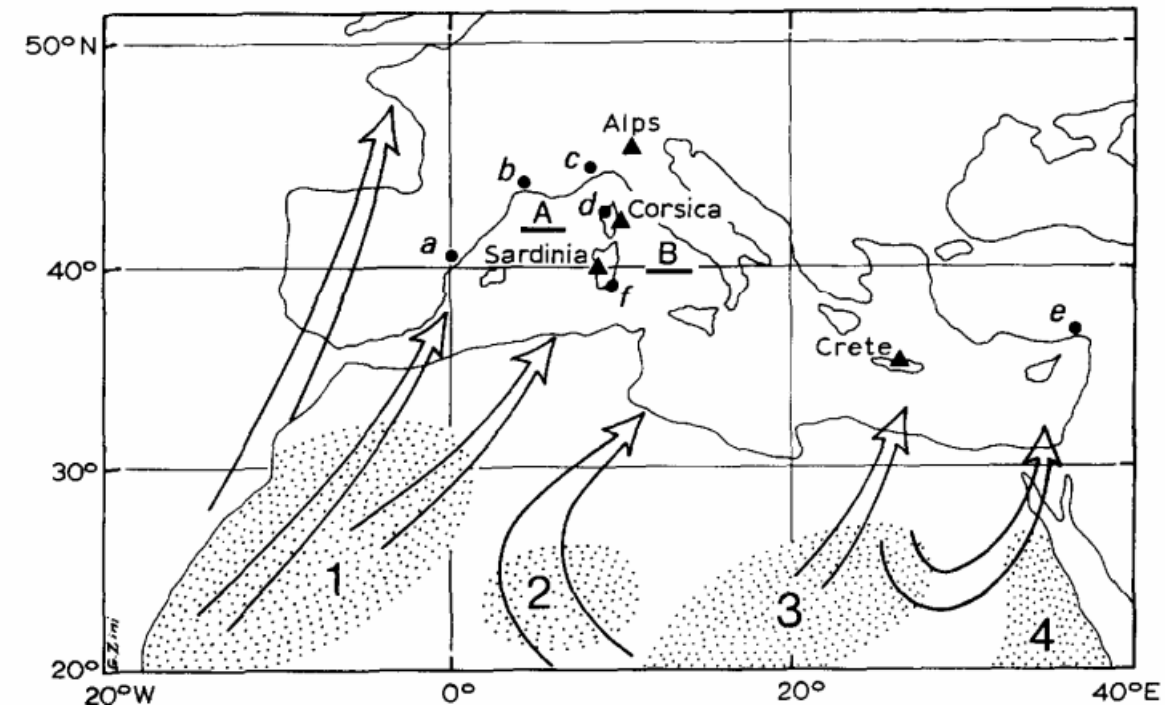

Fig. 1

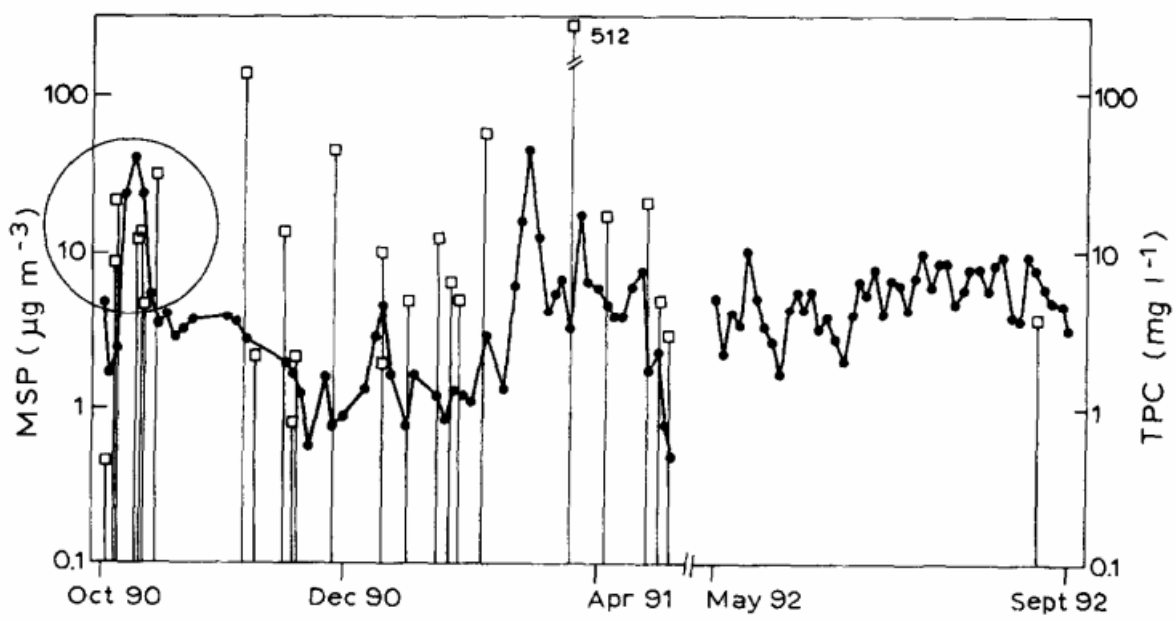

Fig. 2

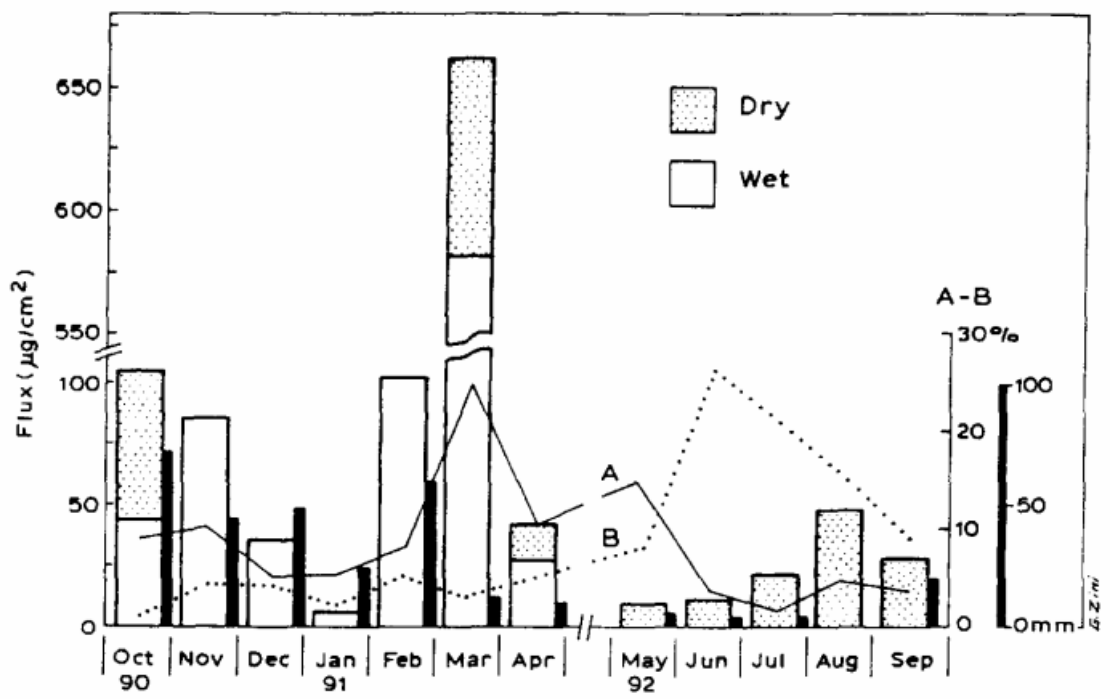

Fig. 3 

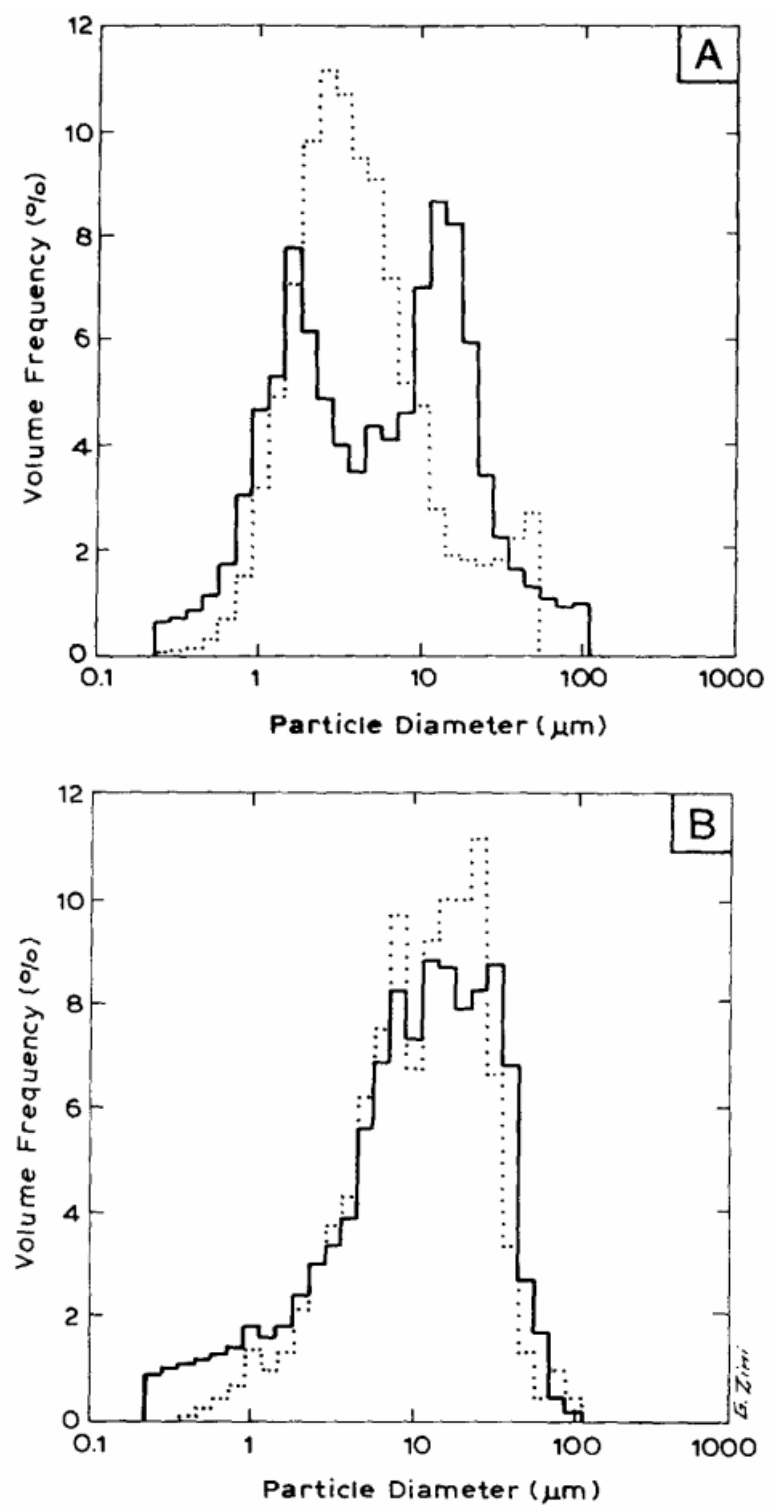

Fig. 12
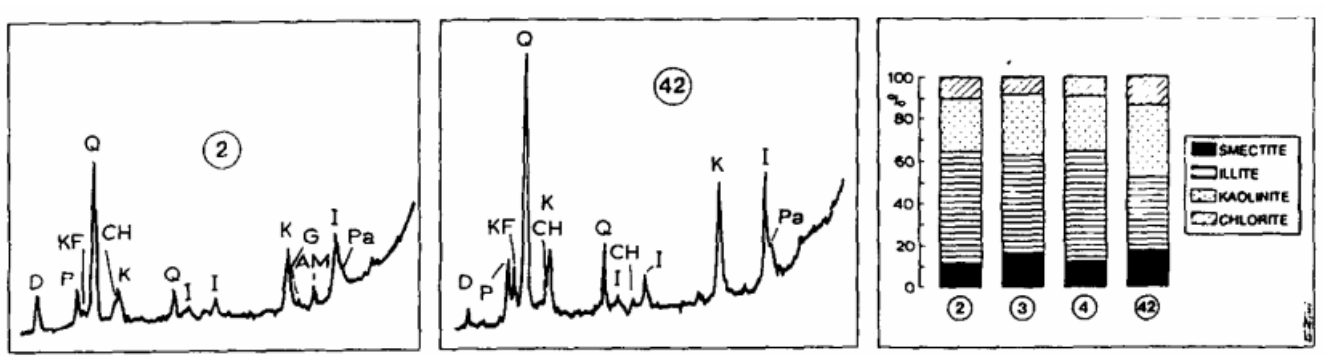

Fig. 5 


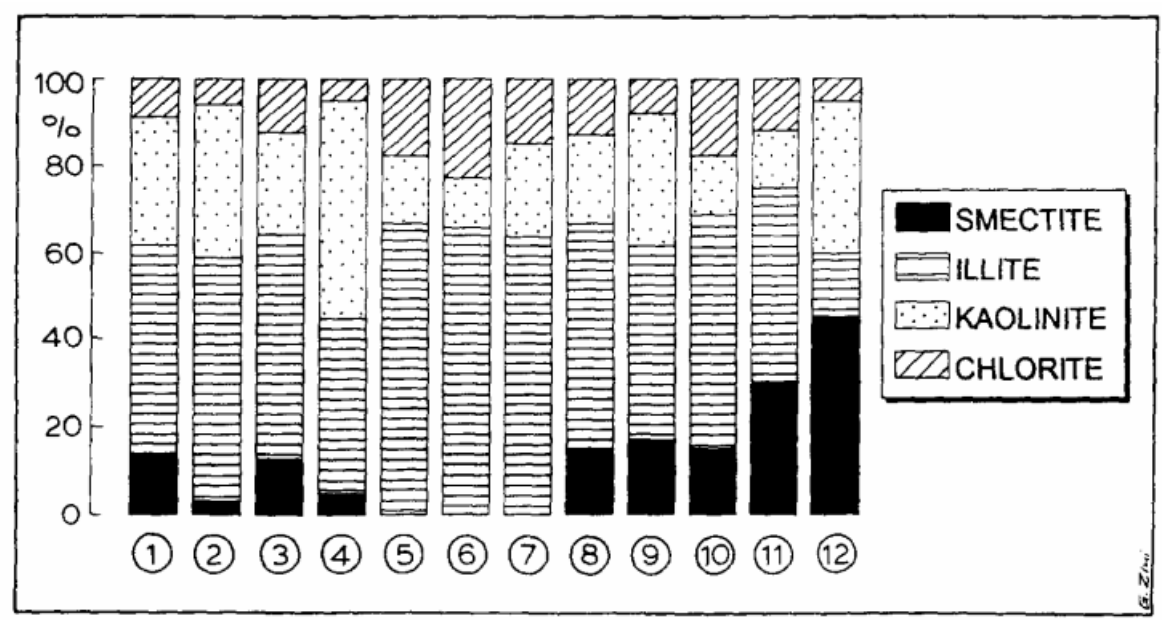

Fig. 6 